\title{
Mechanisms of mass and heat transport during Barrovian metamorphism: A discussion based on field evidence from the Central Alps (Switzerland/northern Italy)
}

\author{
Alfons Berger, ${ }^{1}$ Stefan M. Schmid, ${ }^{2}$ Martin Engi, ${ }^{3}$ Romain Bousquet, ${ }^{4}$ \\ and Michael Wiederkehr ${ }^{5}$ \\ Received 13 October 2009; revised 11 October 2010; accepted 1 November 2010; published 11 February 2011.
}

[1] Tectonic and metamorphic data for the Central Alps (Switzerland/Italy) are used to discuss this classic example of a Barrovian metamorphic terrain, notably the evolution of its thermal structure in space and time. Available P-T-t data indicate variable contributions of advective and conductive heat transport during collision and subsequent cooling and exhumation. Some areas experienced a prolonged period of partial melting while other areas, at the same time, show but moderate heating. The Barrow-type metamorphic field gradient observed in the final orogen is the result of two distinct tectonic processes, with their related advective and conductive heat transport processes. The two tectonic processes are (1) accretion of material within a subduction channel related to decompression and emplacement of high-pressure units in the middle crust and (2) wedging and related nappe formation in the continental lower plate. The second process postdates the first one. Wedging and underthrusting of continental lower plate material produces heat input into lower crustal levels, and this process is responsible for predominantly conductive heat transport in the overlying units. The interacting processes lead to different maximum temperatures at different times, producing the final Barrovian metamorphic field gradient. The south experienced rapid cooling, whereas the north shows moderate cooling rates. This discrepancy principally reflects differences in the temperature distribution in the deeper crust prior to cooling. Differences in the local thermal gradient that prevailed before the cooling also determined the relationships between cooling rate and exhumation rate in the different areas. Citation: Berger, A., S. M. Schmid, M. Engi, R. Bousquet, and M. Wiederkehr (2011), Mechanisms of mass and heat

\footnotetext{
${ }^{1}$ Institute for Geography and Geology, Copenhagen University, Copenhagen, Denmark.

${ }^{2}$ Institut für Geologische Wissenschaften, Freie Universität Berlin, Berlin, Germany.

${ }^{3}$ Institute of Geological Sciences, University of Bern, Bern, Switzerland.

${ }^{4}$ Institut für Geowissenschaften, Universität Potsdam, Golm, Germany.

${ }^{5}$ Bundesamt für Landestopografie Swisstopo, Landesgeologie, Wabern, Switzerland.
}

Copyright 2011 by the American Geophysical Union. 0278-7407/11/2009TC002622 transport during Barrovian metamorphism: A discussion based on field evidence from the Central Alps (Switzerland/northern Italy), Tectonics, 30, TC1007, doi:10.1029/2009TC002622.

\section{Introduction}

[2] The presence of a Barrovian metamorphic overprint (medium pressure/low to high temperature) is typical of many collisional orogens [e.g., Winter, 2001]. Though common, the processes and causes of regional metamorphism leading to this characteristic pressure and temperature regime are still under debate. Possible heat sources for the development of Barrovian belts have been proposed, and dynamic models involving a range of effects have been discussed for such belts in general [e.g., Richardson and England, 1979; Huerta et al., 1999; Jamieson et al., 1998, 2002; Goffé et al., 2003; Gerya et al., 2004, 2008] and for the Alps in particular [e.g., Bousquet et al., 1997; Roselle et al., 2002; Brouwer et al., 2004; Burg and Gerya, 2005]. Numerical modeling has certainly deepened our understanding of possible causes behind Barrovian belts and stimulated the discussion over their tectonometamorphic evolution. In the case of the Central Alps, these discussions have then provoked further field-based studies. It now seems timely to confront the predictions of numerical models with consolidated field data, such as have recently been presented in the literature, notably on the Central Alps.

[3] The regional metamorphic structure in the Alps was first shown by mapped mineral zone boundaries [e.g., Niggli and Niggli, 1965], then by adding reaction isograds [e.g., Trommsdorff, 1966; Fox, 1975; Thompson, 1976; Frey, 1987] and more recently by thermobarometry [Todd and Engi, 1997]. The consistent patterns visible in the respective maps indicate that these represent the distribution of paleophysical conditions. However, it has become clear that the mineral reactions responsible did not all occur at the same time [e.g., Engi et al., 1995], indeed some of them even may not be related to the same metamorphic cycle [e.g., Nagel et al., 2002; Bousquet et al., 2008]. The physical processes associated with Barrovian metamorphism, as inferred from a combination of modeling and field analysis, exert a strong influence on the subsequent cooling history. The latter has been analyzed in several studies [e.g., Schlunegger and Willett, 1999; Bernet et al., 2001; Vernon et al., 2008], with constraints derived from zircon fission track (ZFT), apatite fission track (AFT), and apatite $\mathrm{U} / \mathrm{He}$ studies [Braun et al., 2002, and literature therein]. Cooling of the actively deforming Alpine crust depends on several 
parameters, including notably the thermal structure that existed prior to cooling.

[4] In this contribution, we discuss the available field evidence regarding the metamorphic and tectonic evolution [e.g., Bousquet et al., 2008; Wiederkehr et al., 2008] and subsequent cooling [e.g., Vernon et al., 2008] of the European Central Alps, i.e., of a typical example of Barrow-type metamorphism. The combination of the modeling approach with modern and up-to-date field-based analyses of the tectonometamorphic evolution of mountain belts is likely to lead to a more complete understanding of the evolution of pressure and temperature in time and space. We thus compare field-based data with relevant results of numerical modeling taken from the literature, results that offer valuable quantitative insights into metamorphic processes of the Earth. Such comparisons are also needed because quantitative models typically address but a parts of the tectonometamorphic evolution, and some models are purely generic, aiming to analyze the effects of a few parameters only. We attempt to critically assess which of the available modeling results address the conditions appropriate for a Barrovian overprint in collisional orogens after subduction, i.e., the conditions of a tectonic scenario that applies to the case of the Central Alps [Burov and Yamato, 2008; Roselle et al., 2002; Stöckhert and Gerya, 2005; Burg and Gerya, 2005; Gerya et al., 2008; Carry et al., 2009]. Since complex tectonic settings must be simplified for numerical simulations, modeling results may reflect assumptions (e.g., on geometry) that may be unrealistic when confronted with field evidence. We submit that the complexities of the natural setting must be utilized to test and enhance our understanding of metamorphic processes, particularly in an area like the Alps with many detailed field studies. We explore this advantage by cross checking available fieldbased data to discuss the tectonometamorphic evolution of the Alps. While this paper concentrates on a transect through the Central Alps, it includes information from neighboring areas as well. A wealth of published field-based information is combined to shed light on the mechanisms of mass and heat transport during Barrovian metamorphism, with the stage being set by the tectonic evolution of the Central Alps.

\section{The Evolution of the "Lepontine Dome" of the Central Alps}

[5] Our discussion of the thermal and tectonic evolution within the Lepontine Dome of the Central Alps (Switzerland/ northern Italy) is restricted to the time interval from $45 \mathrm{Ma}$ to $10 \mathrm{Ma}$. The Lepontine Dome comprises a pile of thick thrust sheets consisting of pre-Triassic basement, separated from each other either by Mesozoic metasediments or by tectonic mélange. Most of these basement nappes are derived from the shelf of the European continent, some of them from a microcontinent (the Briançonnais domain) that was located between the Valais Ocean and the Piemont-Liguria Ocean [e.g., Schmid et al., 2004]. Parts of the Mesozoic cover of the European continental shelf area were sheared off and incorporated into separate nappe stacks; some of these consist exclusively of sedimentary cover material. This is the case, for example, for the Helvetic nappes. In this paper, we refer to such Mesozoic metasedimentary units as "European metasediments." Additional thrust sheets consisting entirely of Mesozoic metasediments were derived from the Valais Ocean; these were thrust above European metasediments along a major thrust referred to as the "Penninic basal thrust" [e.g., Wiederkehr et al., 2008].

[6] Tectonic mélange units that separate major basement and cover units derived from the European and Briançonnais continental units, as well as those derived from the intervening Valais Ocean, may include continent-derived and/or oceanic rock slices [Trommsdorff, 1990; Engi et al., 2001; Berger et al., 2005a]. Such a tectonic mélange constitutes the Adula nappe system and is also found within the Southern Steep Belt (SSB) (Figure 1); these mélanges play an important role in the early metamorphic evolution of the entire area [Engi et al., 2001; Roselle et al., 2002]. The SSB, located immediately north of the Insubric Line (Figure 1), constitutes a tectonic mélange unit that is characterized by steeply inclined north dipping foliations [Milnes, 1974]. It contains exceptionally variable lithologies, comprising various gneisses and metasediments, metabasics, ultrabasics; the SSB mélange unit is also characterized by the widespread occurrence of migmatites [e.g., Knoblauch et al., 1939; Fumasoli, 1974; Burri et al., 2005; Berger et al., 2005a].

[7] The Northern Steep Belt (NSB) constitutes a second steep zone located some $50 \mathrm{~km}$ north of the SSB. It consists of Europe-derived basement nappes and metasedimentary slices derived from the Valais Ocean [e.g., Frey, 1967; Probst, 1980; Steinmann, 1994; Wiederkehr et al., 2008]. These nappes and thrust slices were steepened up during a stage of postnappe folding. The NSB is separated from the SSB by a relatively flat-lying nappe stack, which we refer to as the Central Lepontine (Figure 1). Much of the discussion in this paper concentrates on three areas, one within the SSB (around the town of Bellinzona) and two of them exposing metasediments of the NSB and adjacent units (Val Piora and the Pizzo Molare areas; Table 1 and Figure 1).

[8] In order to discuss the transport of mass and heat, we first present the tectonic scenario, followed by data regarding the conditions of metamorphism. We are aware that the tectonic and metamorphic observations discussed here represent interdependent data sets describing one and the same process operative during the latest stages of Alpine orogeny. For clarity, the two data sets are presented in sections 2.1 and 2.2 .

\subsection{Tectonic Evolution of the Central Alps}

[9] The general tectonic evolution has been exhaustively summarized and discussed in several publications [e.g., Schmid et al., 1996, 1997, 2004; Pfiffner et al., 2000, 2002; Steck, 2008]. Here, we concentrate on a section through the Lepontine area and start the discussion at a time around $45 \mathrm{Ma}$ ago, i.e., a time during which the subduction of units derived from the European, Briançonnais and Valais terranes was starting or already ongoing (see Schmid et al. [1996] for the earlier history). Most HP relics (blueschist and eclogite facies rocks) preserved in the Central Alps 


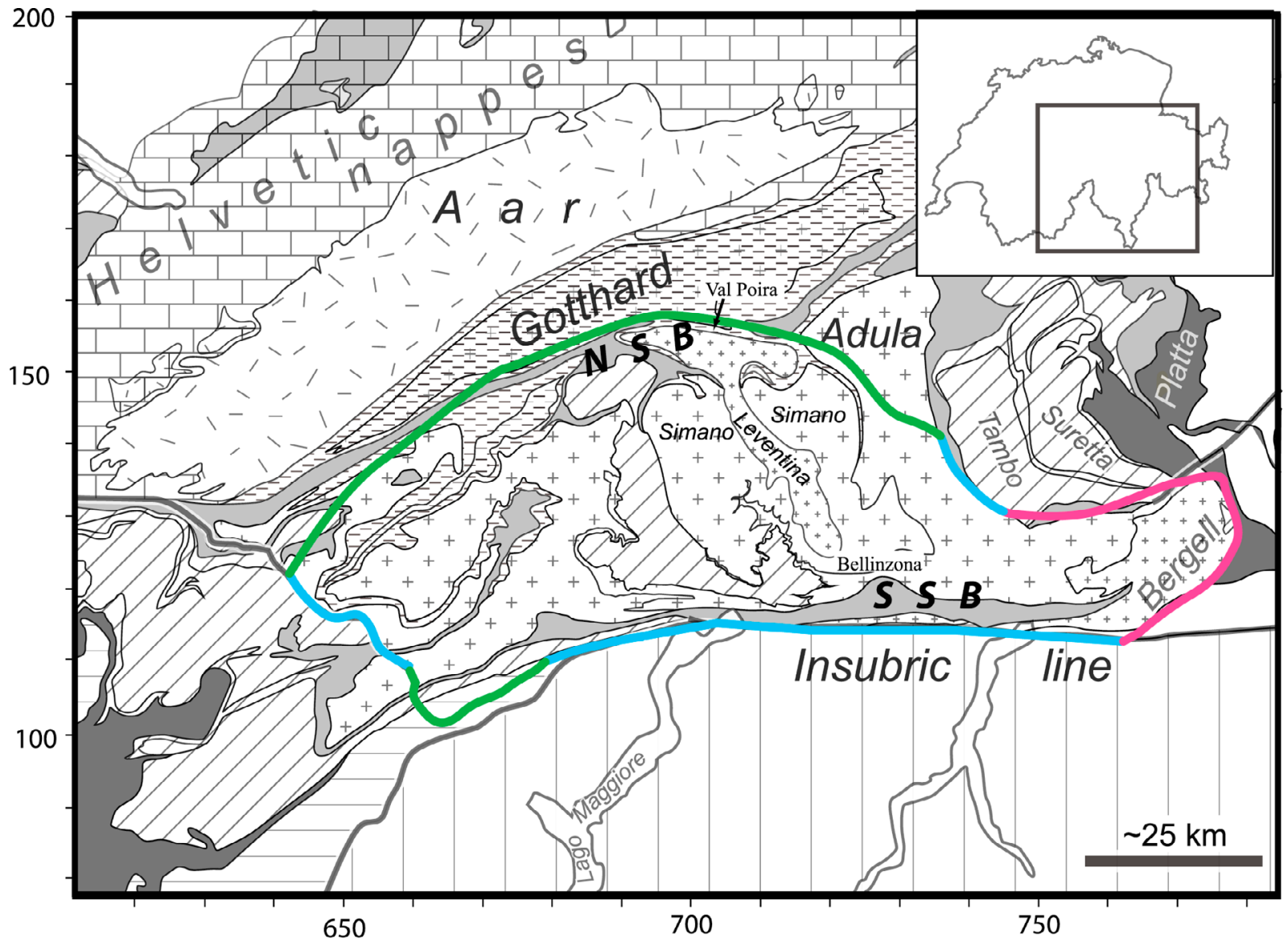

amphibolite facies boundary

boundary at faults contact metamorphic boundary

mineral boundaries

Figure 1. Geological map of the investigated area showing the locations of interest. Tectonic boundaries redrawn after Schmid et al. [2004]. The boundary of amphibolite facies conditions [after Frey et al., 1999] is subdivided into different structural groups (see legend).

formed at around this time. The tectonic evolution was more or less continuous. However, to discuss the complex and polyphase metamorphic evolution in time and space, it is practical to subdivide the evolution into a sequence of deformation phases [e.g., Milnes and Schmutz, 1978; Löw, 1987; Steck, 2008; Wiederkehr et al., 2008]. One needs to be aware, however, that such deformation phases are solely defined by overprinting criteria, and these phases commonly migrate in time and space (see Figure 2 for the names of these deformation phases and their timing).

[10] A crucial biostratigraphical time constraint for the northward propagating orogenic front is provided by the formation of thrust sheets consisting of calcschists (referred to as Bündnerschiefer), derived from the Valais ocean, and the more or less contemporaneous detachment of the Europe-derived Mesozoic shelf sediments from their pre-Triassic basement (Figure 2) [Schmid et al., 1996]. These detached sediments include Late Eocene units [Herb, 1988] that are part of the nonmetamorphic Helvetic nappes, while their substratum formed a substantial part of the Lepontine metamorphic dome, the metamorphism of which must thus postdate this detachment.

[11] The decompression of previously subducted Valais Bündnerschiefer and the mélange units, such as the Adula nappe, goes hand in hand with nappe stacking during the Zapport phase (Figure 2), when the major penetrative foliation formed within these units. Zapport phase nappe stacking overlaps with ongoing thrusting along the Pennine basal thrust (temporal relations to the European foreland are shown in Figure 2; Ferrera deformation of Wiederkehr et al. [2008]). In their southern parts these thrust sheets, including the Adula and SSB tectonic mélange units, were crosscut by the 32 to $30 \mathrm{Ma}$ old Bergell pluton. This magmatic phase provides a perfect time marker, as the pluton, during its solidification some $30 \mathrm{Ma}$ ago [Rosenberg et al., 1995; Davidson et al., 1996; Berger et al., 1996], was involved in nappe refolding during the Cressim phase. Hence, the final emplacement and folding of the Bergell pluton postdates 


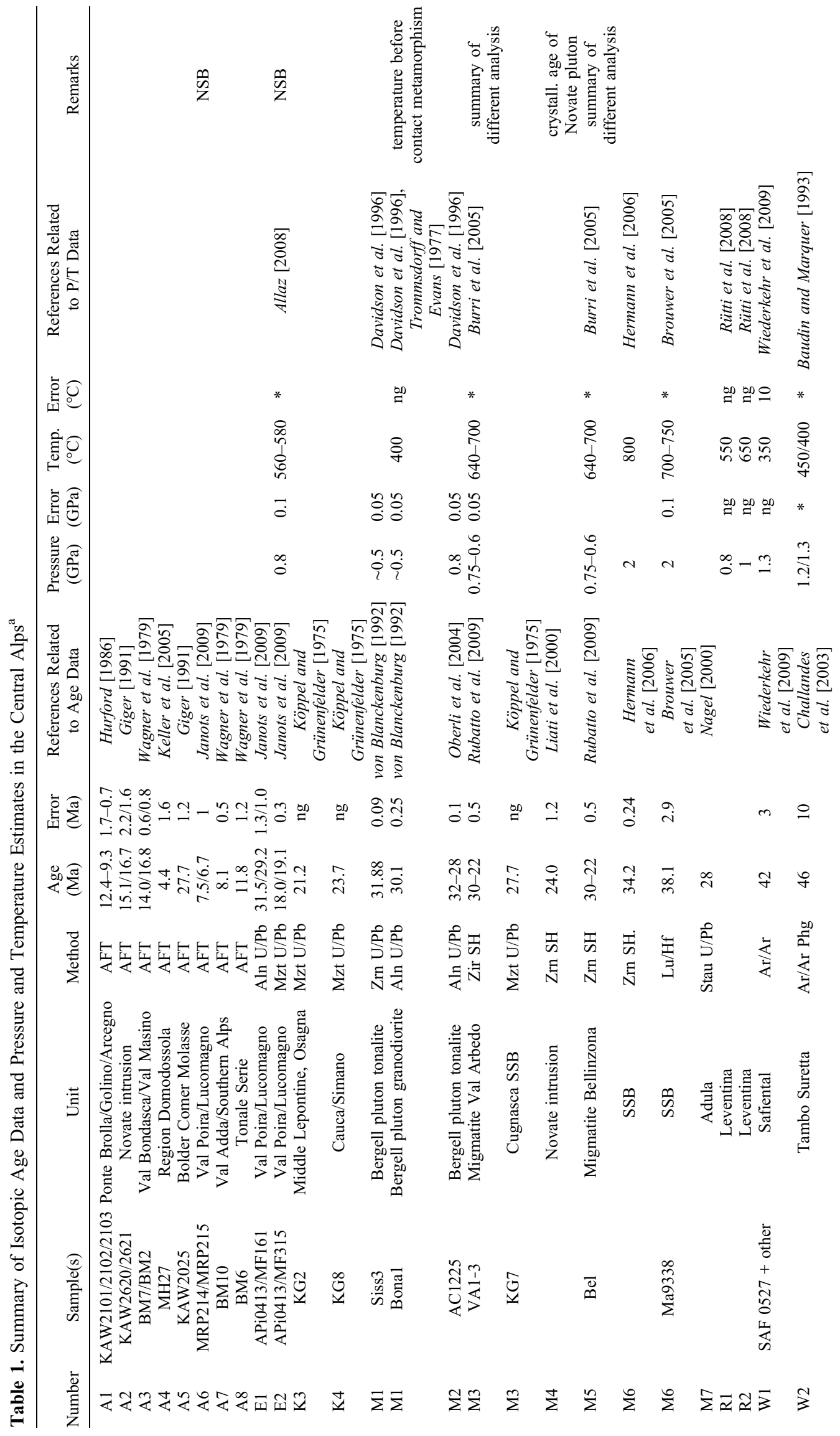




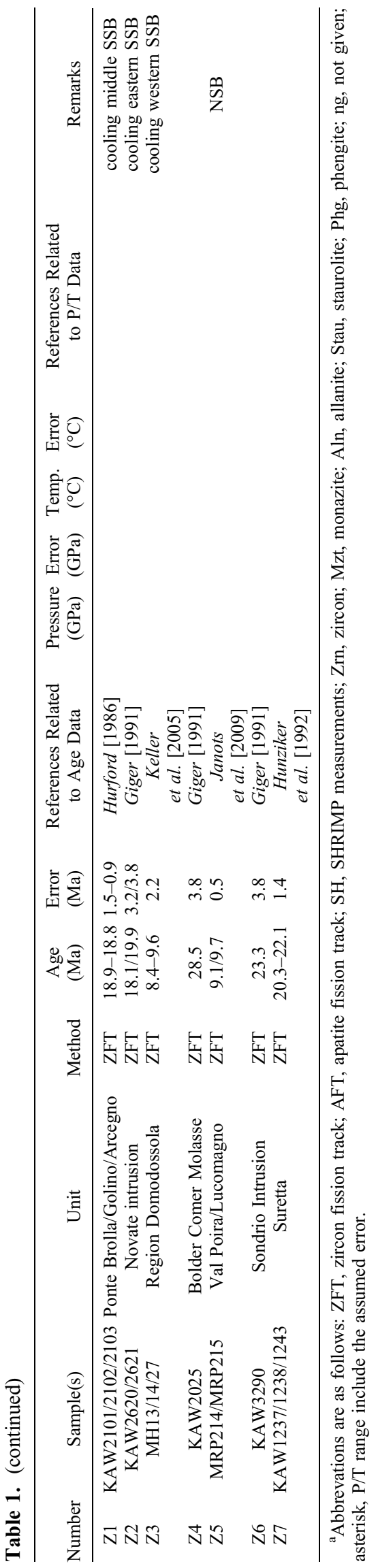

nappe stacking of all of the units derived from the Briançonnais terrane, the Valais Ocean, and the most distal European units comprised in the SSB tectonic mélange.

[12] Nappe stacking of the more proximal parts of the Europe-derived units, now forming the lowermost basement nappes (e.g., the Leventina and Gotthard nappes of Figure 2), must have occurred later than the stacking of the structurally higher nappes. This is evident because the main foliation induced by thrusting within these structurally deepest Europederived basement nappes formed under Barrow-type metamorphic conditions [e.g., Rütti et al., 2008], more precisely during the prograde path of the Barrovian cycle. Hence, this part of the nappe stacking postdates Zapport phase thrusting, which in turn predates the Barrow-type metamorphism. Thrusting of the Gotthard nappe over the Aar massif provides a well-dated example of one of these late-stage top-tothe-north thrusts within the Lepontine area: it occurred under upper greenschist facies conditions no earlier than circa $30 \mathrm{Ma}$ ago and reached lower amphibolite facies conditions as late as $18 \mathrm{Ma}$ ago [Janots et al., 2009]. In summary, thrusting within the structurally higher nappes, i.e., within the Adula mélange unit, the Valais metasediments, as well as the Briançonnais derived nappes predated nappe stacking in the underlying Europe-derived basement nappes (Figure 2). This implies that nappe stacking is in sequence and spans a significant time interval. Later largescale nappe refolding (Domleschg phase) produced strong deformation within the metasediments only, whereas the adjacent basement nappes experienced but moderate strain.

[13] Large amounts of back thrusting associated with rapid erosion of the hanging wall occurred across the Insubric mylonite belt in the SSB. Movements across the Insubric Line occurred over an extended period of time (Figure 2), but the most substantial amounts of vertical and strike slip displacements, related to WNW directed indentation of the Adria block, initiated immediately after the solidification of the Bergell intrusives at circa $30 \mathrm{Ma}$ (see Table 1 for details) and ended before the Insubric line was offset by the Giudicarie Line circa 20 Ma ago [e.g., Schmid et al., 1989; Stipp et al., 2004]. This back thrusting is combined with late-stage back folding at the southern rim of the Lepontine dome that covers approximately the same time span, i.e., from $\sim 33 \mathrm{Ma}$ in the Austroalpine units [Spillmann, 1993] to $\sim 20 \mathrm{Ma}$ in the Simplon area [Keller et al., 2005]. Back folding in the SSB (Cressim phase) went hand in hand with back thrusting across the Insubric Line and was contemporaneous with thickening and significant fore thrusting in the north. There, ongoing stacking of basement nappes further thickened the Europe derived accretionary wedge at the same time period (Figure 2). This interval was characterized by contemporaneous prothrusting and back thrusting (termed proshearing and retroshearing by Beaumont et al. [1994]), such that part of the indenting Adria block, i.e., the Southern Alps, also underwent subordinate back thrusting toward the S-SW. However, the main phase of south directed thrusting in the Southern Alps (Milan belt) postdates the indentation of the Adria block [e.g., Schönborn, 1992; Schumacher et al., 1997] (Figure 2).

[14] The Northern Steep Belt formed much later, after circa $20 \mathrm{Ma}$, when a second phase of postnappe back 
Table 2. Stratigraphic Data of the Discussed Sediments

\begin{tabular}{ccccc}
\hline Number & Unit & Stratigraphic Age & Youngest Absolute Age $^{\mathrm{a}}$ & Reference \\
\hline S1 & Gonfolite Lombardian & Rupelian-Burdigalian & $20 \mathrm{Ma}$ & Sciunnach and Tremolada $[2004]$ \\
S2 & Helvetics & Priabonian & $34 \mathrm{Ma}$ & Herb [1988] \\
S3 & Sardona flysch & Lutetian & $39 \mathrm{Ma}$ & Lihou and Allen $[1996]$ \\
S4 & North Penninic flysch & Ypresian & $50 \mathrm{Ma}$ & Eiermann [1988] \\
\hline
\end{tabular}

${ }^{\mathrm{a}}$ Absolute ages are taken from Gradstein et al. [2004].

folding (Chiera phase; Figure 2) affected the northern parts of the Lepontine dome. This deformation phase took place within a rather short time window and affected a limited area only, i.e., the northern and northwestern parts of the Lepontine dome [Frey, 1967; Wiederkehr et al., 2008]. This back folding is well constrained in time by microstructural relationships between porphyroblast growth and radiometrically dated mineral growth [Wiederkehr et al., 2009; Allaz, 2008; Schwarz, 2008; Janots et al., 2009]. Folding started late, at $\sim 19 \mathrm{Ma}$, with synkinematic growth of some types of porphyroblasts [Janots et al., 2008, 2009], and continued for a brief time interval thereafter; rapid cooling followed, passing through the zircon fission track annealing window some $10 \mathrm{Ma}$ ago (Figure 2). The southern parts of the Lepontine area, on the other hand, had started to cool earlier. There, localized brittle deformation commenced some 25 to $20 \mathrm{Ma}$ ago along the Engadine line [Schmid and Froitzheim, 1993] and in the vicinity of the Insubric line. Within the $\mathrm{SSB}$, cooling below the ductile brittle transition is documented by numerous fission track ages around $20 \mathrm{Ma}$ (Figure 2 and Table 1).

[15] In summary, in the large-scale context of the Central Alps, two major stages of growth are recognized, each related to different deformation processes: (1) the "accretion stage" (stage 1 in Figure 2), involving processes of subduction and partial accretion of oceanic units and oceannear-continent-derived basement units, followed by the accretion of tectonic mélange before and during continentcontinent collision; downward motion during accretion may have been immediately followed by flow reversal and exhumation, accompanied by nappe stacking and (2) the "postcollisional stage" (stage 2 in Figure 2), leading to further thickening of the orogen by continued fore thrusting within the lower plate, leading to the massive accretion of continental basement nappes at relatively shallow depths in the north, combined with contemporaneous back thrusting and back folding in the southern part of the Lepontine dome.

[16] The differential upward displacement of some of the previously subducted units largely occurred by early nappe stacking during the accretion stage. The part of the nappe edifice that formed during exhumation developed in the wedge between the still downgoing lower plate and the more or less stationary, rigid upper plate. We regard nappe stacking combined with erosion (as modeled by Bousquet et al. [1997]), as the principal process that led to decompression. In contrast, we regard propositions for post nappe-stacking extensional collapse [e.g., Selverstone, 2005] as inconclusive for the Central Alps. The postcollisional stage, which further thickened the more proximal
European continental margin, was coupled with a reorganization of rock masses in the middle and lower crust, much as predicted by models of Beaumont et al. [1994]: Simultaneous fore thrusting and back thrusting was caused by the installation of a so-called singularity point near the interface between lower and upper crust in case of the Alps [Schmid et al., 1996]. Only during the post-20 Ma evolution was this configuration modified by northward wedging of the Southern Alpine lower crust beneath the Central Alps, i.e., below the by then essentially passive Insubric line. The insertion of this lower crustal wedge in the south was coupled with thickening in the European upper crust in the north, finally leading to underthrusting of the Gotthard nappe and terminating with the formation of the Northern Steep Belt and the associated rise of the Aar massif (Figures 2 and 3).

\subsection{P-T Evolution During Alpine Orogeny}

[17] Given the tectonic evolution summarized above, which has been reconstructed from structural observations referring to strain, i.e., the movement of rock masses relative to one another, it is now essential to relate these to the available P-T data. We will link the latter to the deformation within individual units (Figures 2, 3, and 4), in order to get a handle on the absolute physical conditions. For more complete information on $\mathrm{P}-\mathrm{T}$ paths and interpretations for individual tectonic units the reader is referred to other publications [e.g., Dale and Holland, 2003; Brouwer et al., 2005; Berger and Bousquet, 2008; Bousquet et al., 2008]. For this analysis, three groups of tectonic units are distinguished: (1) the SSB and southern Adula nappe system, representing deep parts of a subduction-accretion channel; (2) structurally lower Europe-derived nappes, such as the Leventina and Simano nappe, which were accreted during a later stage and that did not experience high-pressure metamorphism; and (3) predominantly Valais Ocean derived units, which underwent pre-Barrovian blueschist facies metamorphism.

[18] The SSB and southern parts of the Adula thrust sheet are characterized by tectonic fragments showing quite variable PT evolutions. Notably included are different HP rocks that formed during the early stages of subduction and accretion. The belt reflects mixing of HP fragments with thrust slices lacking a HP overprint [Brouwer et al., 2005, and references therein]. However, all of these tectonic slices with their differing PT evolutions were assembled at midcrustal conditions, near a point in P-T space at around $0.7 \mathrm{GPa}$ and $700^{\circ} \mathrm{C}$ [e.g., Brouwer et al., 2005; Nagel et al., 2002]. Subsequently, the constituents of the 


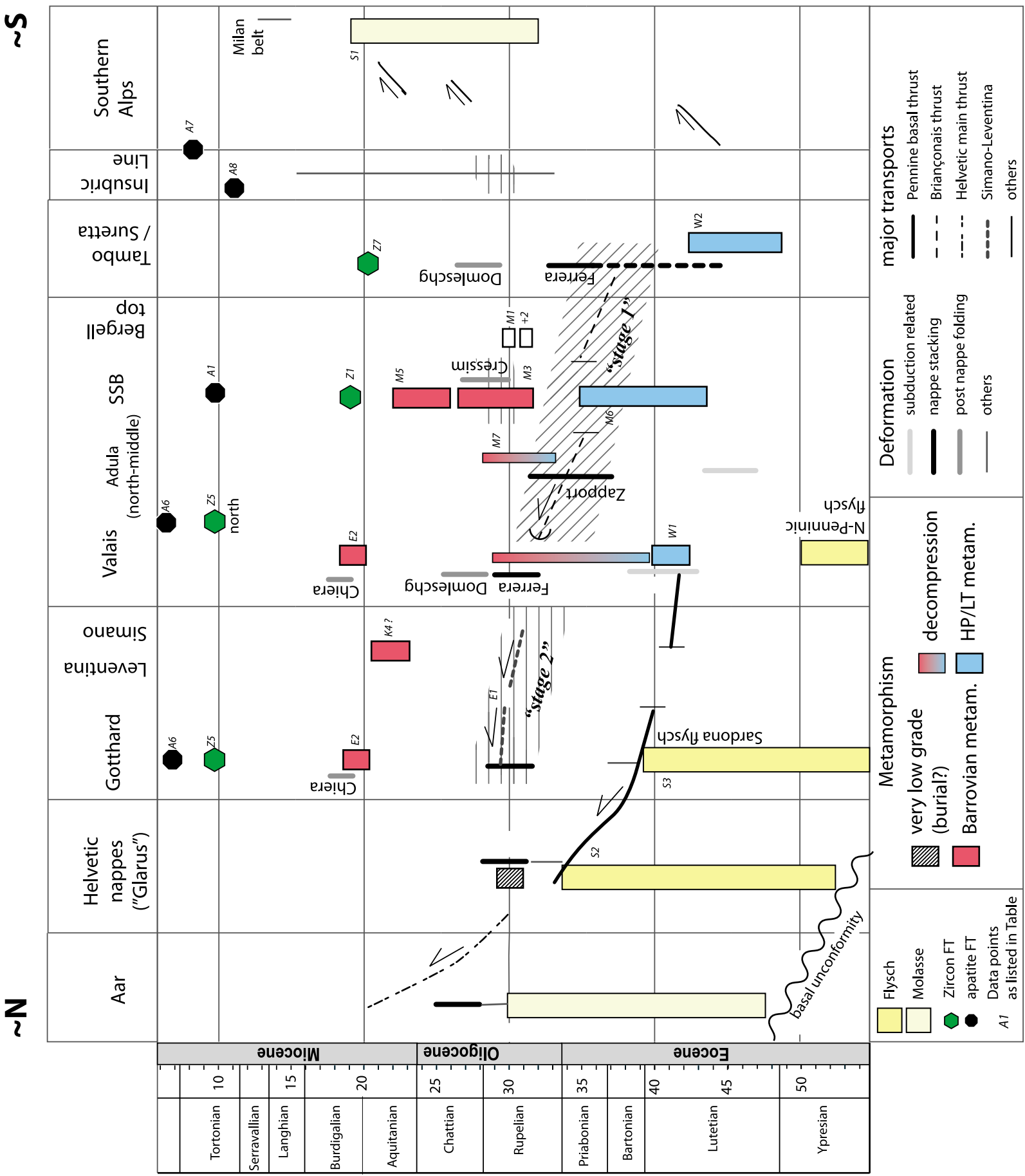

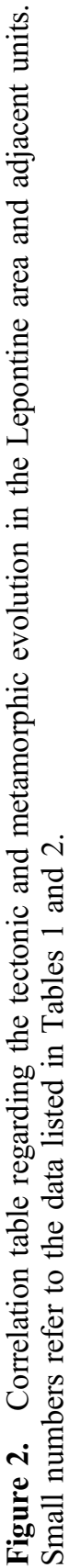




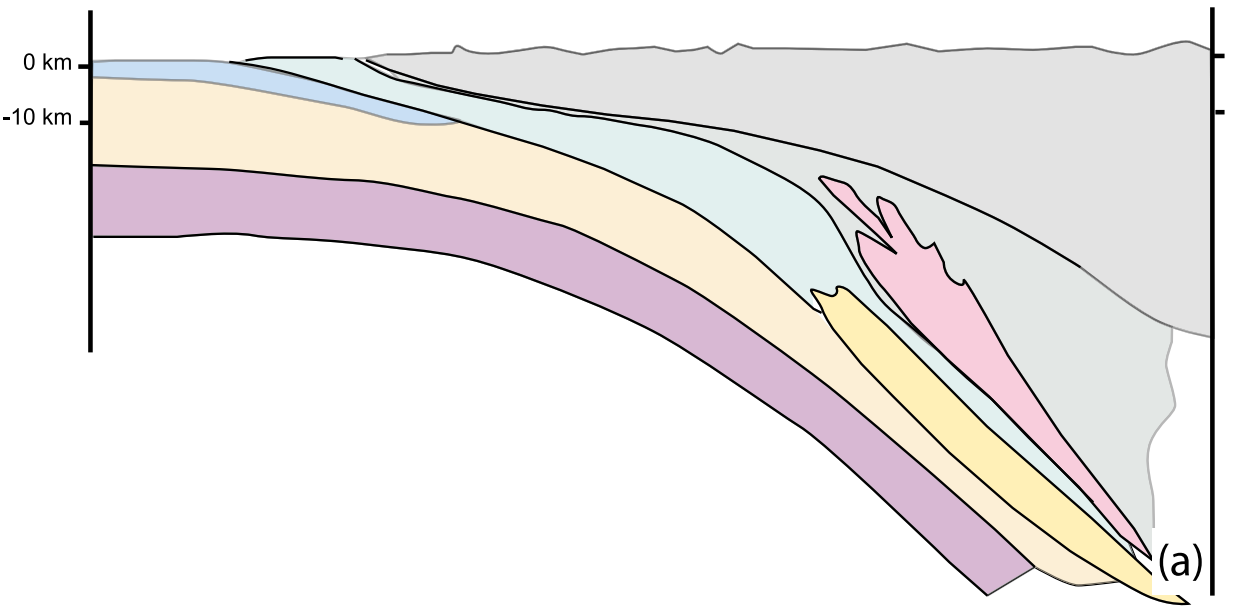

$30 \mathrm{Ma}$
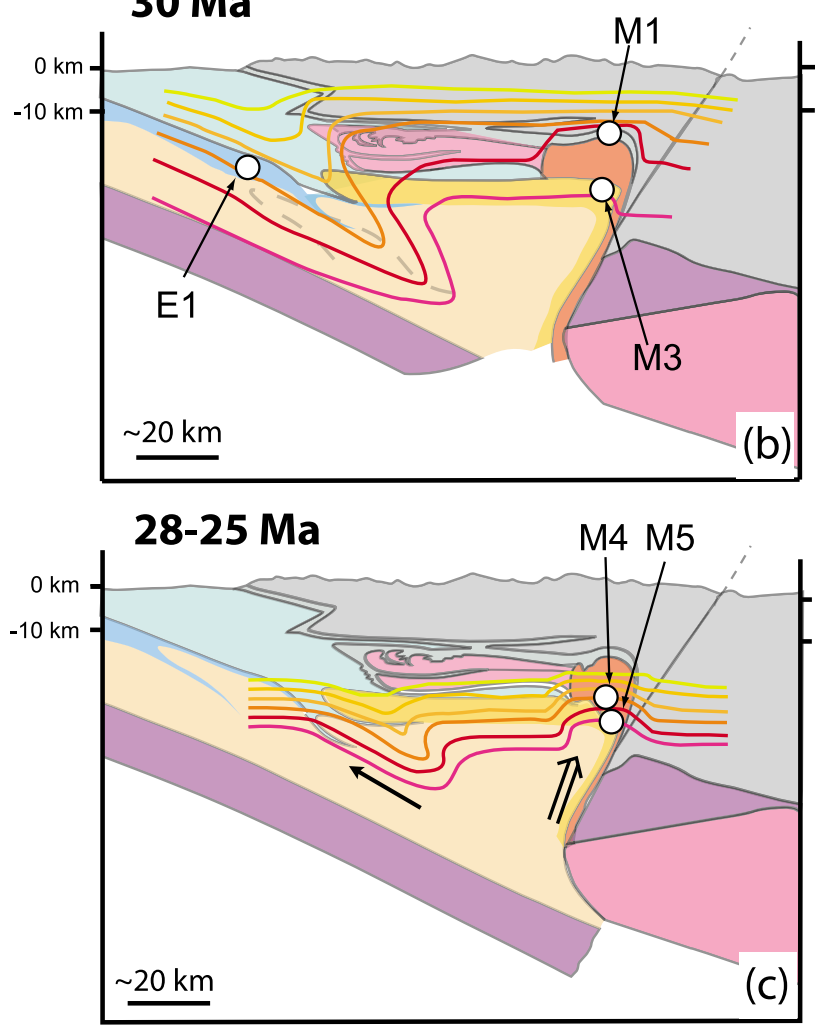

Valais

MÈlange units

Brianconais

crustal rocks

of the Adriatic plate

mantle wedge

of the Adriatic plate

lower crustal rocks

Alpine magmatic rocks

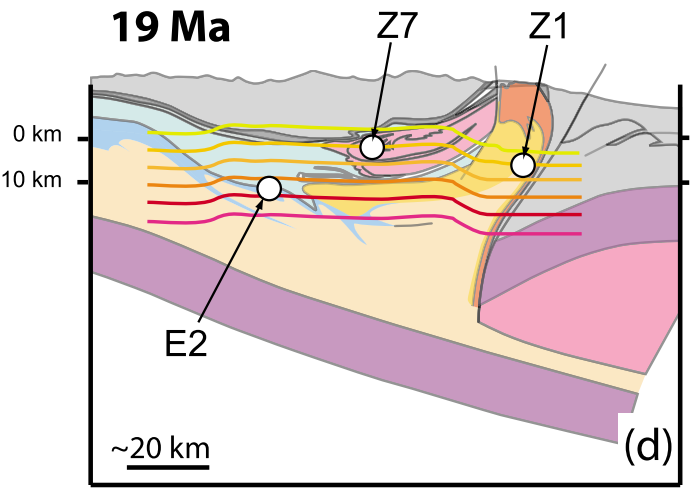

Figure 3 


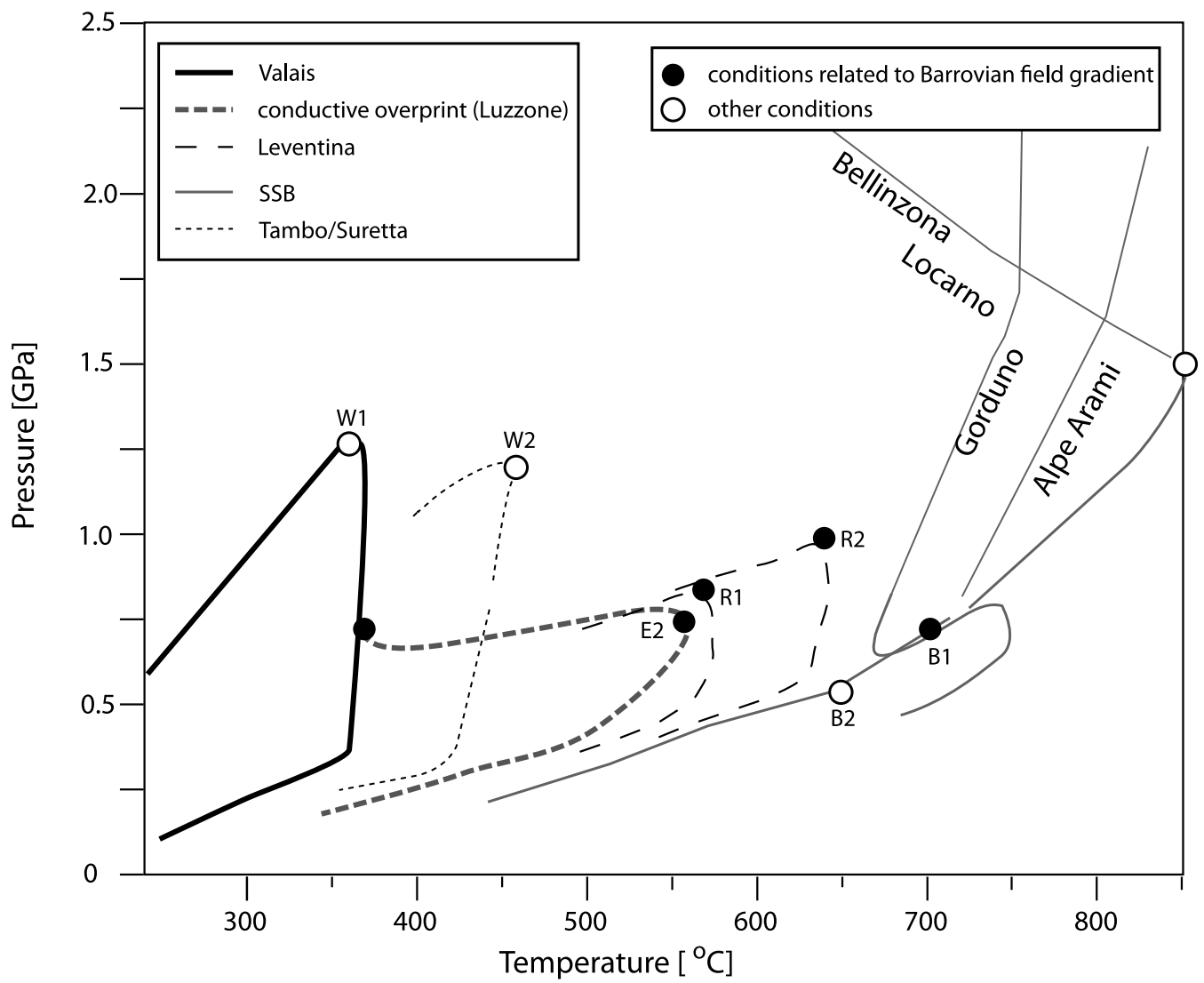

Figure 4. P-T data for the Central Alps. The different line shapes indicate different localities. The letter/ number combinations are "equilibrated" PT data from the literature (Table 1). In the SSB a selection is taken to characterize the evolution inside the TAC (more data in the work of Brouwer et al. [2005, Figure 18]). The black dots can be taken as the Barrovian field gradient [see also Engi et al., 1995]; see Table 1 for data sources.

SSB appear to have followed a joint PT history to lower pressures and temperatures, though the style of deformation during these later stages was variable. The same midcrustal $\mathrm{P}-\mathrm{T}$ conditions are also recorded in the migmatites [Burri et al., 2005] of the SSB. Although the late evolution of the migmatites is not well constrained, the available data indicate that decompression down to $0.5 \mathrm{GPa}$ was associated by minor cooling only $\left(\sim 50^{\circ} \mathrm{C}\right.$ [Burri et al., 2005; Berger et al., 2005b]). The northern parts of the Adula nappe complex record a spatial pressure gradient for the HP stage, with pressures steadily increasing from north to south [e.g., Heinrich, 1986; Dale and Holland, 2003]. The underlying Europe-derived basement nappes record no HP, but burial accompanied by heating, followed by cooling and decompression [e.g., Goffé et al., 2003; Rütti et al., 2008]. These PT data are in line with the tectonic scenario outlined in section 2.1 and sketched in Figure 3. The various Europederived basement nappes differ in transport distances, but they show similar PT histories.

\subsection{Analysis of the Thermal Structure in Different Time Slices}

\subsubsection{The Situation 30 Ma Ago}

[19] To understand the thermal evolution, the situation at around $30 \mathrm{Ma}$ ago is particularly important, hence data pertaining to this time window are first reviewed for different areas. Dating of allanite in Val Piora and surrounding northern areas constrains the temperature in the NSB for the time slice at $30 \pm 1 \mathrm{Ma}$. Janots et al. [2008, 2009] showed that allanite used for dating had developed under greenschist facies conditions along a prograde path, affecting Europederived metasediments that tectonically overly the Gotthard basement nappe. At around $30 \mathrm{Ma}$, Valais metasediments at the eastern rim of the Lepontine dome already had undergone decompression and reached greenschist facies conditions [Wiederkehr et al., 2008, 2009]. In the south, however, SHRIMP zircon data and monazite ages demonstrate that anatectic leucosomes formed at that same time within the SSB [Schärer et al., 1996; Gebauer, 1996; Berger et al.,

Figure 3. Inferred thermal structure in profile view and interpreted tectonic evolution (the latter is modified after Schmid et al. [1996]). (a) Subduction/accretion stage, (b) situation at $30 \mathrm{Ma}$, (c) situation at 28-25 Ma, and (d) situation at $19 \mathrm{Ma}$. In addition to the tectonic evolution, inferred isotherms are drawn; these are based on key data marked by numbers (see Table 1). 

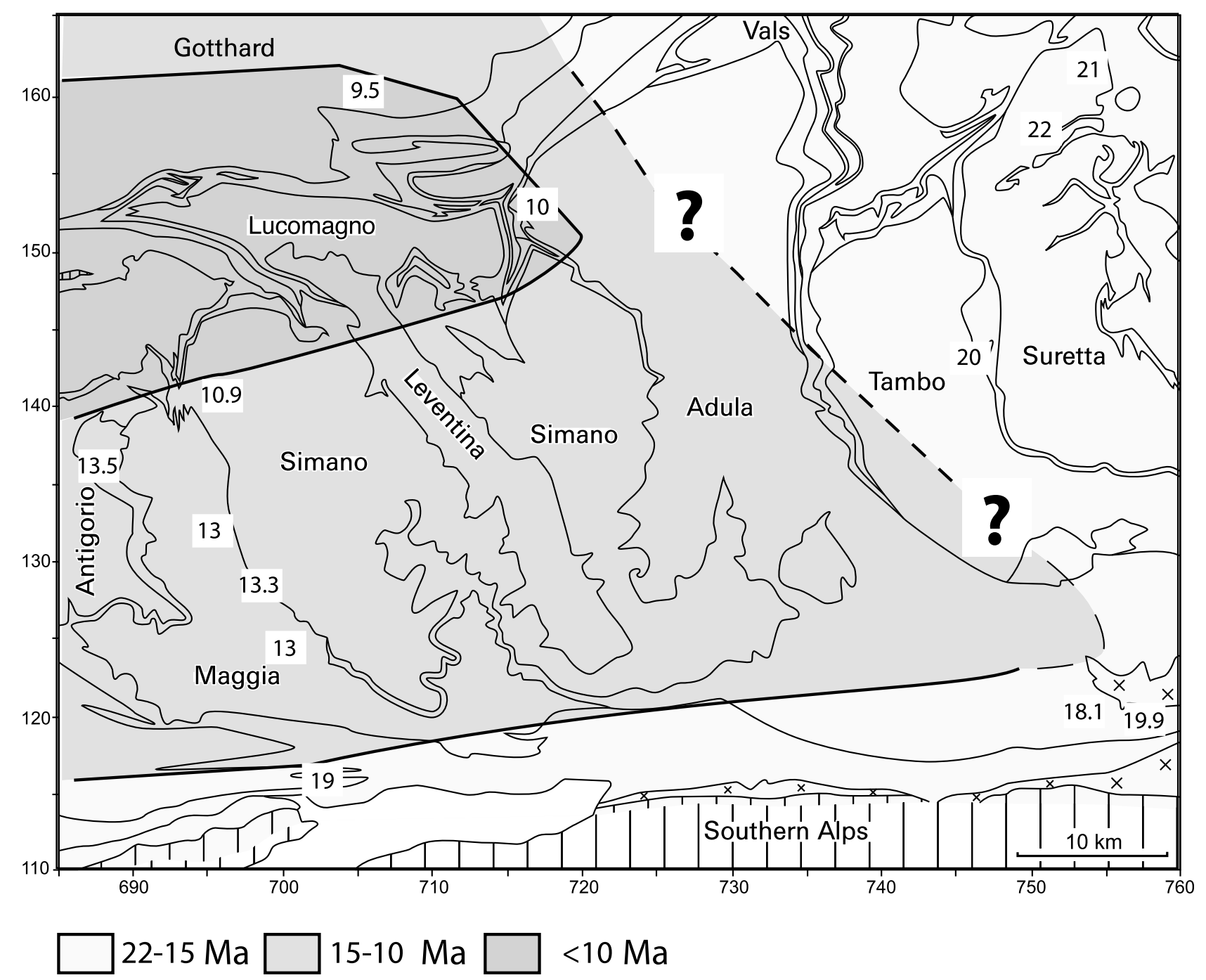

Figure 5. Map of the central Lepontine dome and the available zircon FT data. Tectonic boundaries are from Berger et al. [2005a]; data shown are ages in Ma (see Table 1). The fine stippled line delimits the amphibolite facies belt (kyanite-in isograd); the coarse stippled line is the uncertainty between ages $<20 \mathrm{Ma}$ and $>20 \mathrm{Ma}$ (no zircon FT data in the central Lepontine). See text for discussion.

2009; Rubatto et al., 2009]. These melts locally developed by breakdown of white mica, though in most places melting was caused by influx of aqueous fluid [Burri et al., 2005; Berger et al., 2008]. At that time the Bergell intrusive sheet within the SSB was still at a partially molten stage [Oberli et al., 2004].

[20] The studies just cited establish a well defined anchor near $30 \mathrm{Ma}$ in the overall diachronic evolution: The southern parts of the nappe pile in the Lepontine dome had already undergone postnappe folding under Barrovian upper amphibolite conditions, with migmatites forming in the SSB and the nearby Bergell pluton still solidifying, while in the northern parts of the Lepontine nappe formation and crustal thickening was still ongoing. There, the prograde metamorphic path had not nearly reached its thermal maximum yet [Janots et al., 2009]. The northern units of the future Lepontine area, which were to become part of the amphibolite facies belt, were merely in the vicinity of $450^{\circ} \mathrm{C}$ at that time. The depth of the $450^{\circ} \mathrm{C}$ isotherm in the NSB can be indirectly inferred from pressure estimates of greenschist facies rocks that formed at about that temperature [Mullis, 1996; Livi et al., 2002] albeit somewhat later during the evolution of the belt. These studies indicate pressures of approximately $0.4 \mathrm{GPa}$ for the thermal maximum peak (reached $\sim 19$ Ma ago [Janots et al., 2009]), corresponding to a depth of some $10 \mathrm{~km}$ (similar values were obtained from retrodeformation studies (see Figure 8 of Schmid et al. [1996]). Valais units that underwent blueschist facies metamorphism [Bousquet et al., 2002] in the north experienced decompression between $30 \mathrm{Ma}$ and the thermal maximum at around $19 \mathrm{Ma}$ [Wiederkehr et al., 2009]. By the end of this decompression the Barrovian overprint in the Valais units attained temperatures similar to those within the neighboring European units. Note that the units of the northern lower European crust (e.g., Leventina nappe) reached maximum temperatures of only $550^{\circ} \mathrm{C}$, much lower 


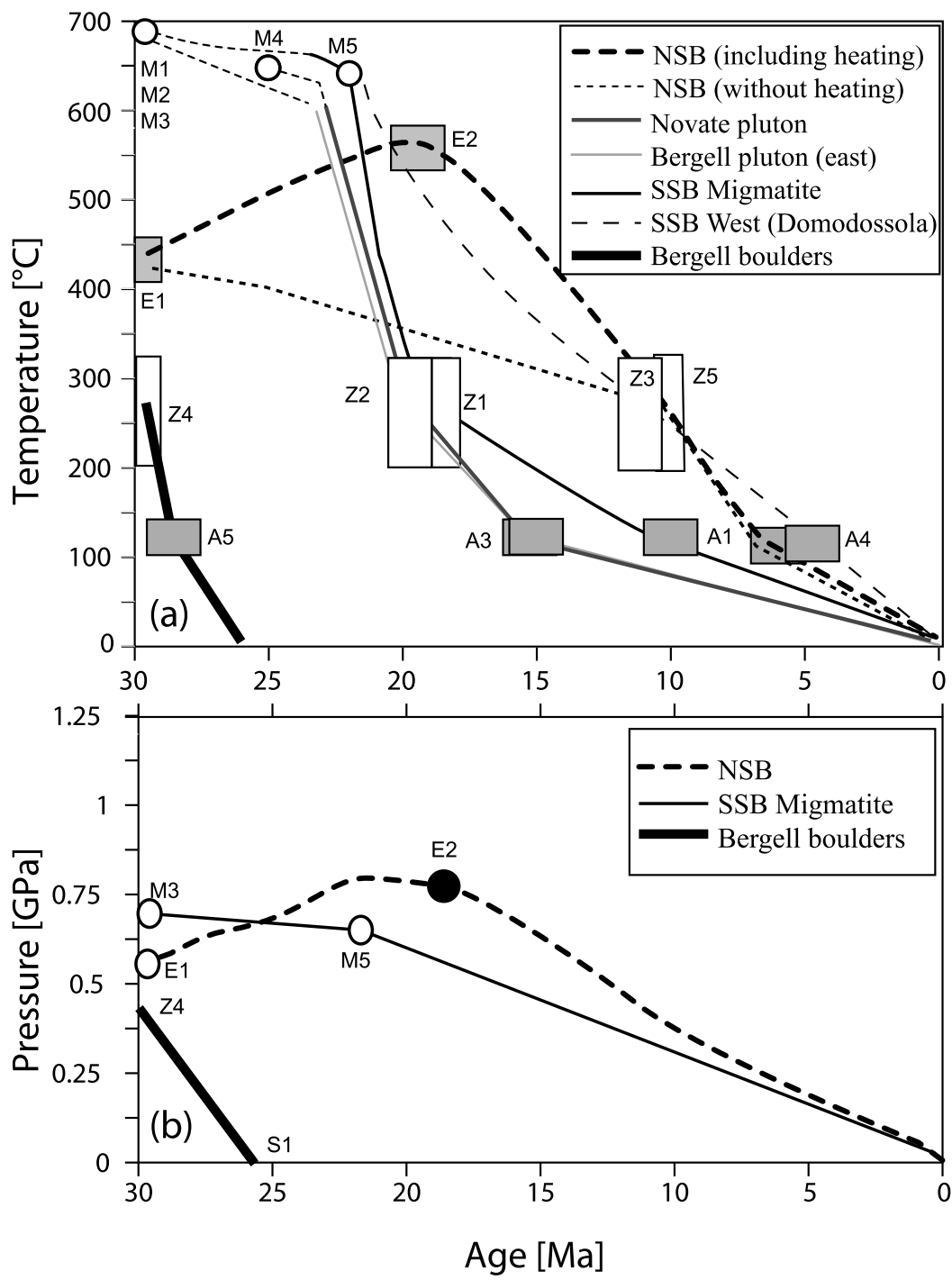

Figure 6. T-t and P-t data for different positions in the Lepontine. (a) Temperature-time evolution for the southern parts of the Lepontine dome. Lines connect localities with similar evolutions. In addition, data for Bergell boulders in the Como Molasse are included [Giger, 1991; Giger and Hurford, 1989]. (b) Pressure-time evolution for the northern and the southern Lepontine. Data for this diagram are sparse. Despite a different temperature history, the pressure history for the SSB and the NSB seems similar (see text for discussion). Letter/number combinations refer to data listed in Tables 1 and 2 .

than those attained in the SSB [e.g., Todd and Engi, 1997; Rütti et al., 2008].

[21] The Bergell pluton induced contact metamorphism along its eastern border (located near the top of the pluton), where temperatures prior to contact metamorphism were below $450^{\circ} \mathrm{C}$ [Trommsdorff and Evans, 1977; Trommsdorff and Connolly, 1996]. The Bergell pluton at $30 \mathrm{Ma}$ was at its emplacement stage; hence the $450^{\circ} \mathrm{C}$ isotherm was located outside the contact aureole and above the Bergell pluton. Pressures preserved at the eastern rim of the Bergell pluton are $\sim 0.4-0.5 \mathrm{GPa}$ [Davidson et al., 1996]. Therefore, the preintrusive thermal regime at the top of the Bergell pluton is similar to that of the nonsubducted European units in the north. A spatial uncertainty is related to the position of the migmatites in the westerly part of the SSB (the samples are constrained by pressure data from the migmatites [Burri et al., 2005]). Taking the highest temperatures and pressures of $0.7 \mathrm{GPa}$ deduced for the time of migmatization, we calculate a point for the $\sim 700^{\circ}$ isotherm that is located at a depth of $\sim 19 \mathrm{~km}$, i.e., some $7 \mathrm{~km}$ below the top of the present Bergell pluton.

\subsubsection{The Situation 19 Ma Ago}

[22] The SSB cooled across the zircon fission track (ZFT) annealing window at similar times, i.e., 30-25 Ma ago, in the area from the Bergell pluton to the area around Bellinzona and to Val Maggia (Figures 5 and 6). Magnetic and petrological data show that this part of the Lepontine dome was tilted toward the east prior to $19 \mathrm{Ma}$ ago [Davidson et al., 1996; Rosenberg and Heller, 1997]. Unfortunately, it is not clear at what depth cooling occurred, 
as no pressure estimates exist for this time interval. Tectonic shortening at around $19 \mathrm{Ma}$ led to uplift of the European crust in the north. By that time metasediments (and directly adjacent basement units) reached their maximum temperatures. As shown by Janots et al. [2008, 2009], new monazite formed under Barrovian conditions close to the thermal maximum (Figure 1). This maximum reached the $560^{\circ}-580^{\circ} \mathrm{C}$ temperature range, at pressures between 0.6 and $0.8 \mathrm{GPa}$ [Allaz, 2008; Wiederkehr et al., 2009; Todd and Engi, 1997] (Table 1). The sediments underwent heating owing to late stage conductive relaxation of the (colder) thermal structure inherited from subduction (see later discussion on underthrusting and conductive heat transport). This overprint has long been recognized, as the isograds and isotherms crosscut all of the tectonic contacts. Essentially postkinematic assemblages in the different metasediments show the overprint due to late stage heating [Wiederkehr et al., 2008, 2009].

\subsubsection{The Cooling History of the Lepontine Dome}

[23] Major parts of the Lepontine Dome cooled below the zircon annealing temperature during the 22 to $10 \mathrm{Ma}$ time interval (Figure 5) [Rahn, 2005, and literature therein]. However, FT zircon ages are younger in the west than in the east [Schmid et al., 1989] and in the NSB [Janots et al., 2009]. Zircon FT ages in the Bergell area are older than those in the central Maggia nappe and in the western SSB [Hurford, 1986; Keller et al., 2005; Vernon et al., 2008; Rosenberg and Berger, 2009] (Figure 6). Although data along strike are sparse in the SSB, the available data indicate that the SSB underwent fast cooling $\left(<100^{\circ} / \mathrm{Ma}\right)$ after partial melting (Figure 6 and Table 1). Early cooling of the Bergell area and in the eastern and central parts of the SSB (Figure 6) was particularly rapid. The three tectonic units adjacent to the north, south and east of the Bergell area show evidence of substantial heating near the plutonic contact only. Hence the Bergell area represents the surface of an upward extrusion of hot magmatic masses. Cooling in their adjacent units (except in the west) was comparable to the evolution in a contact metamorphic aureole, i.e., the volume that was thermally affected is small, hence subsequent cooling was rapid (Figures 1, 3 and 6). By contrast, the NSB cooled at lower rates, and some $10 \mathrm{Ma}$ later. The timing and rate of cooling inside the NSB was similar in the SW parts of the Lepontine dome, in the area of Domodossola (Figure 6).

\section{Discussion of the Tectonometamorphic Evolution}

[24] The above summary of the evolution highlights differences in the P-T-t paths and differences in the time when $\mathrm{T}_{\max }$ was reached in the Barrovian terrane. Numerical models cited earlier show that Barrovian heating can hardly be explained by a single process. Energy contributions that yielded the temperature increase documented in the belt include a combination of well documented factors: Upward transport of hot HP fragments into the middle crust [Engi et al., 2001; Roselle et al., 2002; Gerya et al., 2008], addition of radioactive material at certain positions [Huerta et al., 1999; Engi et al., 2001] and viscous heating [Burg and Gerya, 2005]. The Alps show that the transport of HP pits and related rocks [Engi et al., 2001] and of melts [Brouwer et al., 2004] contribute to the thermal evolution. The absolute magnitude of other factors may be considered debatable. However, the influence of these different heat sources fail to explain the difference in the P-T-t path between SSB and NSB as shown above (e.g., Figures 4 and 6). The pattern of the metamorphic evolution cannot be explained without taking at least two different tectonic processes (Figure 3) into account. These are, as summarized above, (1) accretion of material in the subduction channel leading to heating, decompression, and emplacement of HP units into the middle crust (Figure 3a) and (2) wedging and related nappe formation within the continental lower plate (Figure $3 \mathrm{~b}$ and $3 \mathrm{c}$ ). At the same time as wedging occurred in the lower plate, extrusion processes were active along a steep, major boundary at the southern end of the Barrovian field area (Figure 3c). Such a scenario accounts for the differences in temperature and in the T-t paths between the northern and southern parts of the Lepontine dome. The two processes invoked (wedging in the lower plate and steep extrusion) are in line with the different P-T-t paths in the northern and southern parts (Figure 4). In addition, the present spatial relationships between isotherms (and/or mineral isograds) and tectonic contacts demonstrate a late stage portion of conductive heat transport into the northern part of the Lepontine dome (Figure 3d). Section 3.1 presents a more extensive discussion of the extrusion tectonics and of processes in the northern Lepontine dome.

\subsection{Vertical Extrusion Tectonics in the SSB}

[25] The available structural and P-T-t data indicate vertical extrusion of the SSB hot rock masses relative to the adjacent areas to the south and north, i.e., the Southern Alps and the Lepontine areas north of the SSB, respectively. Immediately after emplacement the Bergell intrusives, the pluton together with the SSB was decoupled from the Southern Alps across the Insubric Line, as well as from the central and northern Lepontine Dome.

[26] There is evidence indicating that, despite this rapid vertical extrusion, the rock masses constituting the SSB, including the Bergell intrusive sheet, remained at $>640^{\circ} \mathrm{C}$ between $\sim 32$ and 22 Ma [e.g., Rubatto et al., 2009] (Figure 6 and Table 1). Petrological and geochronological data indicate only a minor decrease in temperature during this time interval [Berger et al., 2005b; Burri et al., 2005; Rubatto et al., 2009]. Two questions arise: First, which process provided the heat that induced high-temperature Barrovian conditions? Second, why was cooling so slow over such an extended time interval? While not all of the potential heat sources and sinks can be well estimated, it is clear that different processes need to be combined to reach $700^{\circ} \mathrm{C}$ at pressures of $\sim 0.7 \mathrm{GPa}$ (compare different numerical models summarized in Figure 10 of Berger et al. [2008]). The major heat sources affecting the SSB are (1) advection by vertical escape of hot HP fragments (common in the SSB [see Engi et al., 2001; Berger et al., 2005a]), (2) accretion of highly radioactive upper crustal material [Bousquet et al., 1997; Engi et al., 2001; Roselle et al., 2002; Goffé et al., 2003], (3) shear or viscous heating [Burg and Gerya, 2005], and 
(4) episodic intrusion of melts [Brouwer et al., 2004]. The preservation of temperatures $>640^{\circ} \mathrm{C}$ over a long time interval and during vertical extrusion requires continuous heat input into a limited volume of rocks to prevent the vertically extruding volumes from cooling substantially. In order to counteract heat loss, it is likely that the extruding rock volume incorporated partial melts generated in the middle crust. Advective heat transport by magmas (generated by fluid-induced melting [Berger et al., 2008]) provides an efficient heat input into levels now exposed in the SSB. The presence of such melts during the 30-25 Ma time interval is documented by the occurrence of magmatic intrusions (Bergell and Novate intrusions; Table 1), and by variably deformed leucosomes within the vertically extruding SSB [Rubatto et al., 2009]. The presence of such magmatic bodies implies that partial melting occurred at even higher temperatures and greater depths, and that melts were transported upward. Hence, heat transport in the SSB was dominantly advective and caused by the upward displacement of both melts and solid rocks. This is consistent with the vertical extrusion scenario. It should be pointed out that, if melt migration into the SSB migmatite belt remained important after $25 \mathrm{Ma}$, then the young ages of (multiply rimmed) zircons from SSB leucosomes [Rubatto et al., 2009] may reflect that process; hence cooling in the presently exposed levels of the SSB may have started soon after $25 \mathrm{Ma}$.

\subsection{Underthrusting of the Lower Europe-Derived Basement Nappes and the Role of Conductive Heat Transport}

[27] In the northeastern corner of the Lepontine dome the Barrovian isograds crosscut an earlier thermal structure and all tectonic structures associated with final nappe stacking, including structures formed during the first phase of postnappe folding [Wiederkehr et al., 2008, 2009]. This has to be explained by dominantly conductive heat transport in the northern part of the Lepontine dome, possibly with a minor advective component due to fluids. Our tectonic scenario involves underthrusting and ongoing accretion of slices of relatively cold European basement in the form of basement nappes. This brings overlying units at higher temperatures in contact with underthrusting colder ones, causing a transient inverse thermal gradient. Such underthrusting and accretion of basement slices derived from the European foreland led to further thickening within the lower plate. The newly accreted units underwent heating [Janots et al., 2009], while the overlying units record a low thermal gradient [Wiederkehr et al., 2008]. The primary differences in temperature between the underthrusted basement units and the overlying metasedimentary Valais units account for the heat transport in the northeastern corner of the Lepontine Dome at this stage.

[28] The rate of conductive heat transport is controlled by conductivity and differences in heat content. The calculation of this rate depends on the initial advectively generated heat content and on the heat production in the particular units. However, the purely conductive heat transport in one dimension can be used to get at least an impression of the order of magnitudes. Temperature differences propagate on the order of $1^{2} / \kappa$ [e.g., Turcotte and Schubert, 2002] (where 1 is the distance and $\kappa$ is thermal diffusivity). Taking $\kappa=$ $10^{-6} \mathrm{~m}^{2} \mathrm{~s}^{-1}$ [see Turcotte and Schubert, 2002], the typical time for purely conductive heat transport is around $0.8 \mathrm{Ma}$ for $5 \mathrm{~km}$ and $3.2 \mathrm{Ma}$ for $10 \mathrm{~km}$. These time spans are in the range of the uncertainties of the dated Barrovian metamorphic overprint in this area [Allaz, 2008; Wiederkehr et al., 2009].

\subsection{Differences in Cooling History Across a Barrovian Field Area}

[29] Different cooling histories have been proposed for the SSB and the NSB [Rubatto et al., 2009; Janots et al., 2009] (Figure 6). For the SSB the cooling rates, after $T_{\max }$ was reached, are in the range of $100^{\circ} \mathrm{C} / \mathrm{Ma}$, based on $\mathrm{U} / \mathrm{Pb}$ zircon data in migmatites, crystallization ages in aplites, and related ZFT data [Hurford, 1986; Giger and Hurford, 1989; Giger, 1991; Rubatto et al., 2009]. In contrast, the NSB shows significantly lower cooling rates of $\sim 30^{\circ} \mathrm{C} / \mathrm{Ma}$ [Janots et al., 2009]. These differences reflect differences in the tectonometamorphic evolution of the two areas (Figures 2, 3, and 6). Configurations with hotter material in the middle crust, far from representing a steady state thermal structure, have been analyzed by numerical experiments, e.g., so-called "hot channel" models [Gerya et al., 2008]. These numerical models indicate long-term elevated temperatures followed by fast cooling (e.g., green tracking point in the work of Gerya et al. [2008]). Some of their results bear striking similarities with observations in the SSB.

[30] Cooling rates calculated using different thermochronometers are relatively robust (Figure 6), but we have no information on exhumation rates. As shown in the section on thermal structure, the local thermal gradient in the SSB is very different from that in the NSB. The lack of barometers recording the temperature evolution in the lowtemperature range recorded by the FT age data prevents us from deriving reliable exhumation rates. Cooling and exhumation may be connected in the case of the Bergell pluton, as boulders eroded from that body were already deposited between 28 and 23 Ma ago (Chattian; timing from Gradstein et al. [2004]). Some of the boulders are Bergell tonalites showing ductile deformation features identical to those exposed in the Bergell pluton today. By assuming a relatively shallow intrusion depth of the magma represented by these boulders $(\sim 0.3 \mathrm{GPa}$; for comparison between boulders and hinterland samples see Oschidari [1991]; note that present-day hinterland samples crystallized at a minimum pressure of $\sim 0.5 \mathrm{GPa}$ [Davidson et al., 1996]), we estimate a minimum exhumation rate of $1.2-1.9 \mathrm{~km} / \mathrm{Ma}$ (using an intrusion age of $32 \mathrm{Ma}$ ). This ignores the additional time needed for sediment transport and sedimentation. In contrast, the presently exhumed Bergell pluton has an unambiguous position within the Alpine mountain belt and records a well-constrained crystallization pressure $(0.5 \mathrm{GPa}$ [Reusser, 1987; Davidson et al., 1996]). These data indicate an apparent average exhumation rate of $0.45 \mathrm{~km} / \mathrm{Myr}$ $(0.45 \mathrm{~mm} / \mathrm{a}$; Figure 6$)$. Using the pressure estimate for the 

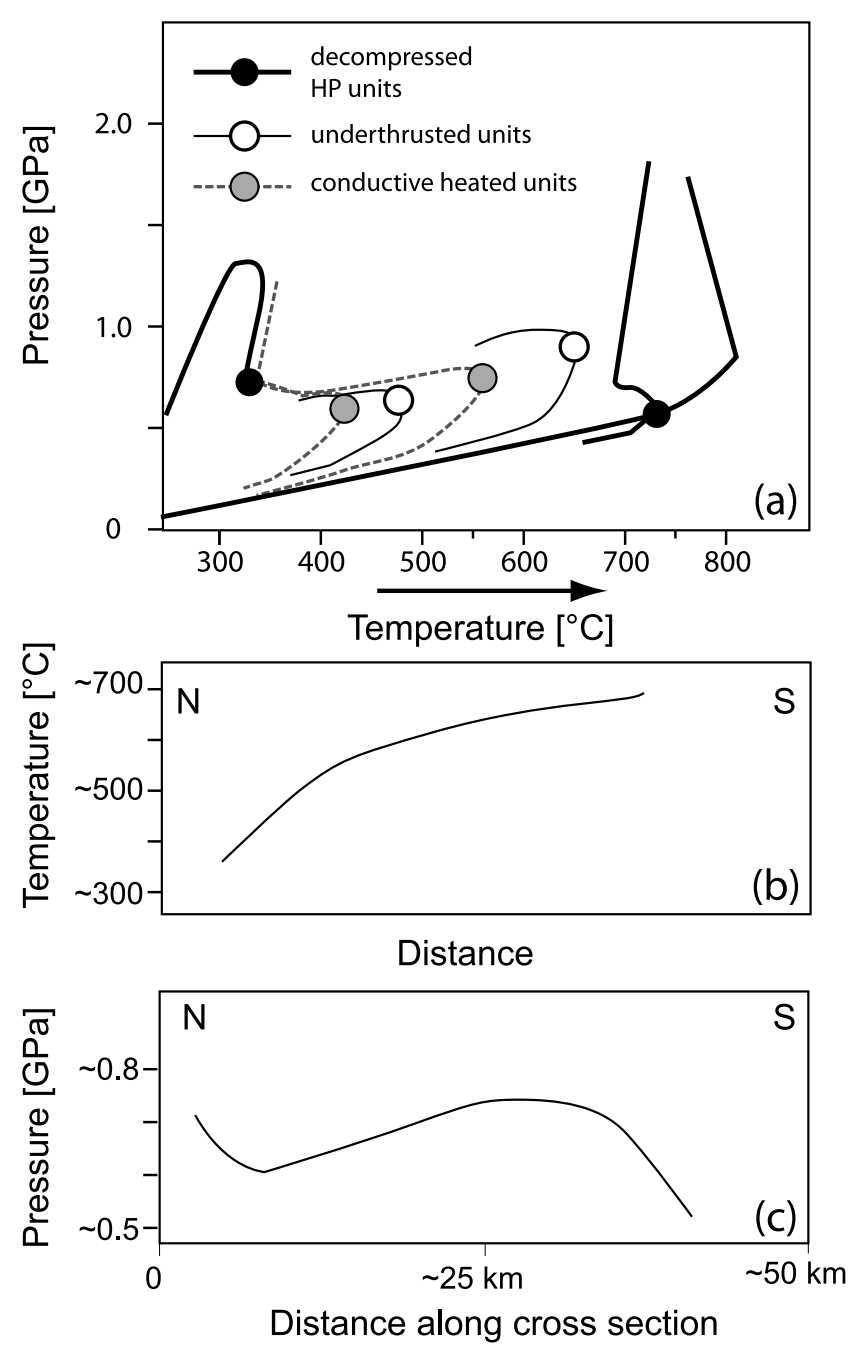

Figure 7. Schematic evolution of P-T data in a Barrovian field area. (a) Schematic P-T evolution for different tectonic units (see Figure 4 for data). (b) Theoretical field gradient of maximum temperatures for the Barrovian metamorphism shown for a N-S profile (compare Figure 9 of Todd and Engi [1997]). (c) Same as Figure 7b but for pressure.

Barrovian conditions of the rocks in the NSB, we obtain an apparent long-term exhumation rate of $1 \mathrm{~km} / \mathrm{Myr}(1 \mathrm{~mm} / \mathrm{a})$. Taking the different areas into account, the exhumation rates in the Lepontine dome vary between 1 and $0.45 \mathrm{~km} / \mathrm{Myr}$. The calculated exhumation rates thus vary by a factor of two, whereas cooling rates vary by factors of three or more (Figure 6). The differences in the calculated cooling and exhumation rates in the northern and southern Steep Belt imply that cooling is not controlled by exhumation processes alone.

[31] The evidence presented is consistent with a local extrusion scenario (of a sheet 5-10 km wide) for the SSB, with a particular cooling and exhumation history of that unit. The combination of fast cooling and rapid exhumation of the SSB during the late Oligocene may explain the extremely high cooling rates. Comparing the Miocene exhumation rates with estimated Quaternary denudation rates, the resulting values are similar $(0.5-0.9 \mathrm{~mm} / \mathrm{a}$ [Wittmann et al., 2007; Reinecker et al., 2008, and references therein]).

\subsection{Consequences Regarding Barrovian Field Areas in General}

[32] The combined tectonic and metamorphic evolution of the Alps presented here has several consequences regarding our understanding of Barrow-type metamorphic field areas in general. As shown above, advective and conductive heat transport are relevant, with their respective roles differing over time and spatially within the orogen. The field gradient reflects different maximum temperatures at different times, and these different maximum temperatures relate to different processes (Figures 3, 6, and 7).

[33] This is consistent with the tectonic evolution of Alpine-type orogens in general, where subduction typically was followed by collision. During the first time interval (stage 1 in Figure 2), advective heat is tectonically transported by HP units to midcrustal levels. This process rapidly reorganizes the thermal structure typical of subduction settings, as has been modeled numerically [Roselle et al., 2002; Goffé et al., 2003; Gerya et al., 2004]. However, exhumation of tectonic fragments (a few $\mathrm{km}$ in size, as observed in TAC units [Engi et al., 2001]) along the subduction channel does not transport sufficient heat to produce the Barrovian overprint (compare exhumation of HP units in the Western Alps). During a subsequent time interval, and in addition to advective heat transport, stacked basement units contribute sufficient heat to produce Barrovian conditions via thickening of the continental lower plate by underthrusting and accretion. The thickening of the lower plate during collision has a threefold effect: (1) transported basement units add further radiogenic material to the system; (2) the nappes advect heat toward more external, previously colder parts of the emerging orogen; and (3) the included lower crustal wedge transports additional heat into the central part of a thickened crust, with upper plate material displacing colder, lower plate material. The maximum temperatures reached (at pressures $<\mathrm{P}_{\max }$ ) are the consequence of heat redistribution following the exhumation of HP units and their emplacement at middle crustal levels, followed by wedging. It appears that both of these processes are required for Barrovian conditions to be attained (as borne out by numerical experiments; see for example Figure 10 of Berger et al. [2008]). HP relics are commonly found in Barrovian field areas, and so is evidence of a thickened crust caused by continent-continent collision (e.g., Spain [Ábalos et al., 2003] and Bohemian massif [O’Brien, 2000]).

\section{Conclusions}

[34] The comparison of the thermal evolution in the Southern Steep Belt with that within the Northern Steep Belt of the Central Alps indicates that, during the same time interval of orogeny, different heat transport processes dominated in these two regions. This disparity in the processes is controlled by differences in the tectonic evolution and results in differences in the thermal structure at a relatively small 
scale, i.e., on the order of $50 \mathrm{~km}$. In detail, the example of the Alps may be unique owing to the details known regarding the geometry and the particular kinematics within this small orogen. Nonetheless, the general situation bears many similarities with other orogens. Notably, the distinction of areas (and periods) dominated by advective heat transport versus areas (and periods) of essentially conductive heat transport is thought to be a general feature, primarily controlled by local tectonics and magmatism. Analysis of the cooling history down to the zircon FT annealing temperature of an area turns out to be strongly influenced by the prior thermal structure established. In order to integrate data regarding the cooling history into the geological history, the transient precursor situation needs to be estimated [Braun et al., 2002]

[35] Acknowledgments. We thank T. Waight for corrections in the text. M. Ballèvre and an anonymous reviewer provided helpful comments. The second author acknowledges financial support from the Alexander von Humboldt Foundation.

\section{References}

Ábalos, B., P. Puelles, and J. I. Gil Ibarguchi (2003), Structural assemblage of high-pressure mantle and crustal rocks in a subduction channel (Cabo Ortegal, NW Spain), Tectonics, 22(2), 1006, doi:10.1029/ 2002TC001405.

Allaz, J. (2008), Metamorphic evolution in the northern Central Alps: Linking ${ }^{39} \mathrm{Ar}-{ }^{40} \mathrm{Ar}$ dating with thermobarometry, Ph.D. thesis, 214 pp., Univ. of Bern, Bern.

Baudin, T., and D. Marquer (1993), Métamorphisme et déformation dans la nappe de Tambo (Alpes centrales suisses): Evolution de la substitution phengitique au cours de la déformation alpine, Schweiz. Mineral. Petrogr. Mitt., 73, 285-299.

Beaumont, C., P. H. Fullsack, and J. Hamilton (1994), Styles of crustal deformation in compressional orogens caused by subduction of the underlying lithosphere, Tectonophysics, 232, 119-132, doi:10.1016/ 0040-1951(94)90079-5.

Berger, A., and R. Bousquet (2008), Subduction related metamorphism in the Alps: Review of isotopic ages based on petrology and their geodynamic consequences, in Tectonic Aspects of the Alpine-DinarideCarpathian System, edited by S. Siegesmund, B. Fügenschuh, and N. Froitzheim, Geol. Soc. Spec. Publ., 298, 117-144.

Berger, A., C. L. Rosenberg, and S. M. Schmid (1996), Ascent, emplacement and exhumation of the Bergell Pluton within the Southern Steep Belt of the Central Alps, Schweiz. Mineral. Petrogr. Mitt., 76, 357-382.

Berger, A., I. Mercolli, and M. Engi (2005a), The central Lepontine Alps: Explanatory notes accompanying the tectonic-geological map sheet Sopra Ceneri (1:100,000), Schweiz. Mineral. Petrogr. Mitt., 85, 109-146.

Berger, A., N. C. Scherrer, and F. Bussy (2005b), Equilibration and disequilibration between monazite and garnet: Indication from phase-composition and quantitative texture analysis, J. Metamorph. Geol., $23,865-880$.

Berger, A., T. Burri, P. Alt-Epping, and M. Engi (2008), Tectonically controlled fluid flow and water assisted melting in the middle crust: An example from the Central Alps, Lithos, 102, 598-615, doi:10.1016/j.lithos.2007.07.027.

Berger, A., C. L. Rosenberg, and U. Schaltegger (2009), Stability of monazite and allanite in partially molten rocks and their isotope dating: Examples from the Central Alps, Swiss J. Geosci., 103, 15-23.

Bernet, M., M. Zattin, J. I. Garver, M. T. Brandon, and J. A. Vance (2001), Steady-state exhumation of the European Alps, Geology, 29, 35-38, doi:10.1130/ 0091-7613(2001)029<0035:SSEOTE $>2.0 . C O ; 2$.

Bousquet, R., B. Goffé, P. Henry, X. Le Pichon, and C. Chopin (1997), Kinematic, thermal and petrological model of the Central Alps: Lepontine metamorphism in the upper crust and eclogitisation of the lower crust, Tectonophysics, 273, 105-127, doi:10.1016/S0040-1951(96)00290-9.

Bousquet, R., B. Goffé, O. Vidal, R. Oberhänsli, and M. Patriat (2002), The tectono-metamorphic history of the Valaisan domain from the Western to the Central Alps: New constraints for the evolution of the Alps, Geol. Soc. Am. Bull., 114, 207-225,
doi:10.1130/0016-7606(2002)114<0207:TTMHOT> $2.0 . \mathrm{CO} ; 2$

Bousquet, R., R. Oberhänsli, B. Goffé, M. Wiederkehr, F. Koller, S. M. Schmid, R. Schuster, M. Engi, A. Berger, and G. Martinotti (2008), Metamorphism of metasediments in the scale of an orogen: A key to the Tertiary geodynamic evolution of the Alps, in Tectonic Aspects of the Alpine-Carpathian-Dinaride System, edited by S. Siegesmund, B. Fügenschuh, and N. Froitzheim, Geol. Soc. Spec. Publ., 298, 393-411.

Braun, J., P. van der Beek, and G. Batt (2002), Quantitative Thermochronology, Cambridge University Press, Cambridge, U. K.

Brouwer, F. M., D. M. A. van de Zedde, M. J. R. Wortel, and R. L. M. Vissers (2004), Late-orogenic heating during exhumation: Alpine PTt trajectories and thermomechanical models, Earth Planet. Sci. Lett., 220, 185-199, doi:10.1016/S0012-821X(04)00050-0.

Brouwer, F. M., T. Burri, M. Engi, and A. Berger (2005), Eclogite relics in the Central Alps: Regional distribution, metamorphic PT-evolution, Lu-Hf ages, and genetic implications on the formation of tectonic mélange zones, Schweiz. Mineral. Petrogr. Mitt., 85, 147-174.

Burg, J.-P., and T. V. Gerya (2005), The role of viscous heating in Barrovian metamorphism of collisional orogens: Thermomechanical models and application to the Lepontine Dome in the Central Alps, J. Metamorph. Geol., 23, 75-95, doi:10.1111/j.1525-1314.2005. 00563.x

Burov, E., and P. Yamato (2008), Continental plate collision, P-T-t-z conditions and unstable vs. stable plate dynamics: Insights from thermo-mechanical modelling, Lithos, 103, 178-204, doi:10.1016/j.lithos. 2007.09.014.

Burri, T., A. Berger, and M. Engi (2005), Tertiary migmatites in the Central Alps: Regional distribution, field relations, conditions of formation and tectonic implications, Schweiz. Mineral. Petrogr. Mitt., 85, 215-232.

Carry, N., F. Gueydan, J. P. Brun, and D. Marquer (2009), Mechanical decoupling of high-pressure crustal units during continental subduction, Earth Planet. Sci. Lett., 278, 13-25, doi:10.1016/j. eps1.2008.11.019.

Challandes, N., D. Marquer, and I. M. Villa (2003), Dating the evolution of $\mathrm{C}-\mathrm{S}$ microstructures: A combined ${ }^{40} \mathrm{Ar} /{ }^{39} \mathrm{Ar}$ step-heating and UV laserprobe analysis of the Alpine Roffna shear zone, Chem. Geol., 197, 3-19, doi:10.1016/S0009-2541 (02)00354-6.

Dale, J., and T. J. B. Holland (2003), Geothermobarometry, P-T paths and metamorphic field gradients of high-pressure rocks from the Adula Nappe, Central Alps, J. Metamorph. Geol., 21, 813-829, doi:10.1046/j.1525-1314.2003.00483.x.

Davidson, C., C. Rosenberg, and S. M. Schmid (1996), Symmagmatic folding of the base of the Bergell pluton, Central Alps, Tectonophysics, 265, 213-238, doi:10.1016/S0040-1951(96)00070-4.

Eiermann, D. (1988), Zur Stellung des Martegnas Zuges, Eclogae Geol. Helv., 81, 269-272.
Engi, M., C. S. Todd, and D. Schmatz (1995), Tertiary metamorphic conditions in the eastern Lepontine Alps, Schweiz. Mineral. Petrogr. Mitt., 75, 347-369.

Engi, M., A. Berger, and G. Roselle (2001), The role of the tectonic accretion channel in collisional orogeny, Geology, 29, 1143-1146, doi:10.1130/0091-7613 (2001)029<1143:ROTTAC $>2.0$.CO;2.

Fox, J. S. (1975), Three dimensional isograds from the Lukmanier Pass, Switzerland, and their tectonic significance, Geol. Mag., 112, 547-564, doi:10.1017/ S0016756800038966.

Frey, J. D. (1967), Geologie des Greinagebietes (Val Camadra, Valle Cavalasca, Val di Larciolo, Passo della Greina), Beitr. Geol. Karte Schweiz, 131, 1-112.

Frey, M. (1987), The reaction-isograd kaolinite + quartz = pyrophyllite $+\mathrm{H}_{2} \mathrm{O}$, Helvetic Alps, Switzerland, Schweiz. Mineral. Petrogr. Mitt., 67, 1-11.

Frey, M., J. Desmons, and F. Neubauer (1999), The new metamorphic map of the Alps: Introduction, Schweiz. Mineral. Petrogr. Mitt., 79, 1-4.

Fumasoli, M. W. (1974), Geologie des Gebietes nördlich und südlich der Iorio-Tonale-Linie im Westen der Gravedona, Ph.D. thesis, Univ. Zurich, Zurich, Switzerland.

Gebauer, D. (1996), A P-T-t path for an (ultra?-) high pressure ultramafic/mafic rock-association and its felsic country-rocks based on SHRIMP-dating of magmatic and metamorphic zircon domainsExample: Alpe Arami (central Swiss Alps), in Earth Processes: Reading the Isotope Code, Geophys. Monogr. Ser., vol. 95, edited by A. Hart and S. R. Basu, pp. 307-328, AGU, Washington, D. C

Gerya, T. V., D. A. Yuen, and W. V. Maresch (2004), Thermomechanical modelling of slab detachment, Earth Planet. Sci. Lett., 226, 101-116, doi:10.1016 j.eps1.2004.07.022.

Gerya, T. V., L. L. Perchuk, and J.-P. Burg (2008), Transient hot channels: Perpetrating and regurgitating ultrahigh-pressure, high-temperature crustmantle associations in collision belts, Lithos, 103, 236-256, doi:10.1016/j.lithos.2007.09.017.

Giger, M. (1991), Geochronologische und petrographische Studien an Geröllen der Gonfolite Lombarda gruppe (Südsschweiz and Norditalien) und ihr Vergleich mit dem alpinen Hinterland, Ph.D. thesis, Univ. of Bern, Bern.

Giger, M., and A. J. Hurford (1989), Tertiary intrusives of the Central Alps: Their Tertiary uplift, erosion, redeposition and burial in the south Alpine foreland, Eclogae Geol. Helv., 82, 857-866.

Goffé, B., R. Bousquet, P. Henry, and X. Le Pichon (2003), Effect of the chemical composition of the crust on the metamorphic evolution of orogenic wedges, J. Metamorph. Geol., 21, 123-141, doi:10.1046/j.1525-1314.2003.00422.x.

Gradstein, F., J. Ogg, and A. Smith (2004), A Geological Time Scale, Cambridge Univ. Press, Cambridge, U. K.

Heinrich, C. A. (1986), Eclogite facies regional metamorphism of hydrous mafic rocks in the central Alpine Adula nappe, J. Petrol., 27, 123-154.

Herb, R. (1988), Eocäne Paläogeographie und Paläotektonik des Helvetikums, Eclogae Geol. Helv., 83, 611-657. 
Hermann, J., D. Rubatto, and V. Trommsdorff (2006), Sub-solidus Oligocene zircon formation in garnet peridotite during fast decompression and fluid infiltration (Duria, Central Alps), Mineral. Petrol., 88, 181-206, doi:10.1007/s00710-006-0155-3.

Huerta, A. D., L. H. Royden, and K. V. Hodges (1999), The effects of accretion, erosion and radiogenic heat on the metamorphic evolution of collisional orogens, J. Metamorph. Geol., 17, 349-366, doi:10.1046/ j.1525-1314.1999.00204.x.

Hunziker, J. C, J. Desmons, and A. J. Hurford (1992), Thirty-two years of geochronological work in the Central and Western Alps: A review on seven maps, Mem. Geol. Lausann, 13, 1-52.

Hurford, A. J. (1986), Cooling and uplift patterns in the Lepontine Alps south central Switzerland and an age of movement on the Insubric Fault Line, Contrib. Mineral. Petrol., 92, 413-427, doi:10.1007/ BF00374424.

Jamieson, R. A., C. Beaument, and P. Fullsack (1998), Barrovian regional metamorphism: Where's the heat?, in What Drives Metamorphism and Metamorphic Reactions?, edited by P. J. Treloar and P. J. O'Brian, Geol. Soc. Spec. Publ., 138, 23-46.

Jamieson, R. A., C. Beaumont, M. H. Nguyen, and B. Lee (2002), Interaction of metamorphism, deformation and exhumation in large convergent orogens, J. Metamorph. Geol., 20, 9-24, doi:10.1046/j.02634929.2001.00357.x

Janots, E., M. Engi, A. Berger, J. Allaz, J.-O. Schwarz, and C. Spandler (2008), Prograde metamorphic sequence of REE minerals in pelitic rocks of the Central Alps: Implications on allanite-monazite-xenotime phase relations from 250 to $610^{\circ} \mathrm{C}, J$. Metamorph. Geol., 26, 509-526, doi:10.1111/j.1525-1314.2008. 00774.x.

Janots, E., M. Engi, D. Rubatto, A. Berger, C. Gregory, and M. Rahn (2009), Metamorphic rates in collisional orogeny from in situ allanite and monazite dating, Geology, 37, 11-14, doi:10.1130/G25192A.1.

Keller, L. M., M. Hess, B. Fügenschuh, and S. M. Schmid (2005), Structural and metamorphic evolution of the Camughera-Moncucco, Antrona and Monte Rosa units southwest of the Simplon line, Western Alps, Eclogae Geol. Helv., 98, 19-49, doi:10.1007/s00015-005-1149-6.

Knoblauch, P., M. Reinhard, and E. Kündig (1939), Geologischer Atlas der Schweiz 1:25000, vol. 11 B1, A. Franke, Bern.

Köppel, V., and M. Grünenfelder (1975), Concordant $\mathrm{U}-\mathrm{Pb}$ ages of monazite and xenotime from Central Alps and the timing of the high temperature Alpine metamorphism: A preliminary report, Schweiz. Mineral. Petrogr. Mitt., 55, 129-132.

Liati, A., D. Gebauer, and M. Fanning (2000), U-Pb SHRIMP dating of zircon from the Novate granite (Bergell, Central Alps): Evidence for OligoceneMiocene magmatism, Jurassic/Cretaceous continental rifting and opening of the Valais trough, Schweiz. Mineral. Petrogr. Mitt., 80, 305-316.

Lihou, J. C., and P. A. Allen (1996), Importance of inherited rift margin structures in the early North Alpine Foreland Basin, Switzerland, Basin Res., 8, 425-442, doi:10.1046/j.1365-2117.1996.00244.x.

Livi, K. J. T., J. M. Ferry, D. R. Veblen, M. Frey, and J. A. D. Connolly (2002), Reactions and physical conditions during metamorphism of Liassic aluminous black shales and marls in central Switzerland, Eur. J. Mineral., 14, 647-672, doi:10.1127/09351221/2002/0014-0647.

Löw, S. (1987), Die tektono-metamorphe Entwicklung der nördlichen Adula-Decke, Beitr. Geol. Karte Schweiz, 161, 1-84.

Milnes, A. G. (1974), Structure of the Pennine Zone (Central Alps): A new working hypothesis, Geol. Soc. Am. Bull., 85, 1727-1732, doi:10.1130/00167606(1974)85<1727:SOTPZC $>2.0 . C O ; 2$.

Milnes, A. G., and H. Schmutz (1978), Structure and history of the Suretta nappe (Pennine Zone), a field study, Eclogae Geol. Helv., 71, 19-33.
Mullis, J. (1996), P-T-t path of quartz formation in extensional veins of the Central Alps, Schweiz. Mineral. Petrogr. Mitt., 76, 159-164.

Nagel, T. (2000), Metamorphic and structural history of the southern Adula nappe (Graubünden, Switzerland), Ph.D. thesis, 103 pp., Univ. of Basel, Basel, Switzerland.

Nagel, T., C. de Capitani, and M. Frey (2002), Isograds and $\mathrm{P}-\mathrm{T}$ evolution in the eastern Lepontine Alps (Graubünden, Switzerland), J. Metamorph. Geol., 20, 309-324, doi:10.1046/j.1525-1314.2002.00368.x.

Niggli, E., and P. Niggli (1965), Karten der Verbreitung einiger Mineralien der alpidischen Metamorphosein den Schweizer Alpen (Stilpnomelan, Alkali-Amphibol, Chloritoid, Staurolith, Disthen, Sillimanit), Eclogae Geol. Helv., 58, 335-368.

Oberli, F., M. Meier, A. Berger, C. Rosenberg, and R. Gieré (2004), ${ }^{230} \mathrm{Th} /{ }^{238} \mathrm{U}$ disequilibrium systematics in $\mathrm{U}-\mathrm{Th}-\mathrm{Pb}$ dating: Precise accessory mineral chronology and melt evolution tracing in the Alpine Bergell intrusion, Geochim. Cosmochim. Acta, 68 , 2543-2560, doi:10.1016/j.gca.2003.10.017.

O'Brien, P. J. (2000), The fundamental Variscan problem: High-temperature metamorphism at different depths and high-pressure metamorphism at different temperatures, in Orogenic Processes: Quantification and Modelling in the Variscan Belt, edited by W. Franke et al., Geol. Soc. Spec. Publ., 179 , 369-386.

Oschidari, H. (1991), Geochemie und Isotopengeochemie an den tertiären Bergeller Plutoniten aus der südalpinen Molasse und dem alpinen Hinterland, Ph.D. thesis, 166 pp., Univ. of Bern, Bern.

Pfiffner, O. A., S. Ellis, and C. Beaumont (2000), Collision tectonics in the Swiss Alps: Insight from geodynamic modeling, Tectonics, 19, 1065-1094, doi:10.1029 2000TC900019

Pfiffner, O. A., F. Schlunegger, and S. J. H. Buiter (2002), The Swiss Alps and their peripheral foreland basin: Stratigraphic response to deep crusta processes, Tectonics, 21(2), 1009, doi:10.1029/ 2000TC900039.

Probst, P. (1980), Die Bündnerschiefer des nördlichen Penninikums zwischen Valser Tal und Passo di San Giacomo, Beitr. Geol. Karte Schweiz, 153, 1-64.

Rahn, M. (2005), Apatite fission track ages from the Adula nappe: Late stage exhumation and relief evolution, Schweiz. Mineral. Petrogr. Mitt., 85, 233-245.

Reinecker, J., M. Danišík, C. Schmid, C. Glotzbach, M. Rahn, W. Frisch, and C. Spiegel (2008), Tectonic control on the late stage exhumation of the Aar Massif (Switzerland): Constraints from apatite fission track and (U-Th)/He data, Tectonics, 27 , TC6009, doi:10.1029/2007TC002247.

Reusser, E. (1987), Phasenbeziehungen im Tonalit der Bergeller Intrusion, Ph.D. thesis, ETH Zurich, Zurich, Switzerland.

Richardson, S. W., and P. C. England (1979), Metamorphic consequences of crustal eclogite production in overthrust orogenic zones, Earth Planet. Sci. Lett. 42, 183-190, doi:10.1016/0012-821X(79)90023-2.

Roselle, G. T., M. Thüring, and M. Engi (2002), MELONPIT: A finite element code for simulating tectonic mass movement and heat flow within subduction zones, Am. J. Sci., 302, 381-409, doi:10.2475/ ajs.302.5.381

Rosenberg, C. L., and A. Berger (2009), On the causes and modes of exhumation and lateral growth of the Alps, Tectonics, 28, TC6001, doi:10.1029/2008TC002442.

Rosenberg, C. L., and F. Heller (1997), Tilting of the Bergell pluton and central Lepontine area: Combined evidence from paleomagnetic, structural and petrolological data, Eclogae Geol. Helv., 90, 345-356.

Rosenberg, C. L., A. Berger, and S. M. Schmid (1995), Observations from the floor of a granitoid pluton: Inferences on the driving force of final emplacement, Geology, 23, 443-446, doi:10.1130/00917613(1995)023<0443:OFTFOA >2.3.CO;2.

Rubatto, D., J. Hermann, A. Berger, and M. Engi (2009), Protracted fluid-induced melting during
Barrovian metamorphism in the Central Alps, Contrib. Mineral. Petrol., 158, 703-722, doi:10.1007/ s00410-009-0406-5.

Rütti, R., D. Marquer, and A. B. Thompson (2008), Tertiary tectono-metamorphic evolution of the European margin during Alpine collison: Example of the Leventina Nappe (Central Alps, Switzerland), Swiss J. Geosci., 101, 157-171, doi:10.1007/s00015008-1278-9.

Schärer, U., M. Cosca, A. Steck, and J. Hunziker (1996), Termination of major ductile strike-slip shear and differential cooling along the Insubric line (Central Alps): U-Pb, Rb-Sr and ${ }^{40} \mathrm{Ar} /{ }^{39} \mathrm{Ar}$ ages of crosscutting pegmatites, Earth Planet. Sci. Lett., 142, 331-351, doi:10.1016/0012-821X(96)00104-5.

Schlunegger, F., and S. Willett (1999), Spatial and temporal variations in exhumation of the central Swiss Alps and implications for exhumation mechanisms, in Exhumation Processes: Normal Faulting, Ductile Flow and Erosion, edited by U. Ring et al., Geol. Soc. Spec. Publ., 154, 157-179.

Schmid, S. M., and N. Froitzheim (1993), Oblique slip and block rotation along the Engadine line, Eclogae Geol. Helv., 86, 569-594.

Schmid, S. M., H. R. Aebli, F. Heller, and A. Zingg (1989), The role of the Periadriatic line in the tectonic evolution of the Alps, in Alpine Tectonics, edited by D. Dietrich and M. P. Coward, Geol. Soc. Spec. Publ., 45, 153-171.

Schmid, S. M., O. A. Pfiffner, N. Froitzheim, G. Schönborn, and E. Kissling (1996), Geophysicalgeological transect and tectonic evolution of the Swiss-Italian Alps, Tectonics, 15, 1036-1064, doi:10.1029/96TC00433.

Schmid, S. M., O. A. Pfiffner, and G. Schreurs (1997), The Pennine Zone, in Deep Structure of the Swiss Alps: Results of NFP/PNR 20, edited by O. A. Pfiffner et al., pp. 60-185, Birkhäuser, Basel, Switzerland.

Schmid, S. M., B. Fügenschuh, E. Kissling, and R. Schuster (2004), Tectonic map and overall architecture of the Alpine orogen, Eclogae Geol. Helv., 97, 93-117, doi:10.1007/s00015-004-1113-x.

Schönborn, G. (1992), Alpine tectonics and kinematic models of the central Southern Alps, Mem. Ist Geol. Mineral. Univ. Padova, 44, 229-393.

Schumacher, M. E., G. Schönborn, D. Bernoulli, and H. Laubscher (1997), Rifting and collision in the Southern Alps, in Deep Structure of the Swiss Alps: Results From NFP/PNR 20, edited by O. A. Pfiffner et al., pp. 186-204, Birkhäuser, Basel, Switzerland.

Schwarz, J.-O. (2008), Porphyroblasts: Textural analysis and a genetic model for garnet-bearing metasediments, $156 \mathrm{pp}$., Ph.D thesis, Univ. of Bern, Bern.

Sciunnach, D., and F. Tremolada (2004), The Lombardian Gonfolite Group in central Brianza (Como and Milano provinces, Italy): Calcareous nannofossil biostratigraphy and sedimentary record of neoalpine tectonics, Eclogae Geol. Helv., 97, 119-131, doi:10.1007/s00015-004-1108-7.

Selverstone, J. (2005), Are the Alps collapsing?, Annu. Rev. Earth Planet. Sci., 33, 113-132, doi:10.1146 annurev.earth.33.092203.122535.

Spillmann, P. (1993), Die Geologie des penninischostalpinen Grenzbereichs im südlichen Berninagebirge, Ph.D. thesis, 279 pp., ETH Zurich, Zurich, Switzerland.

Steck, A. (2008), Tectonics of the Simplon massif and Lepontine gneiss dome: Deformation structures due to collision between the underthrusting European plate and the Adriatic indenter, Swiss J. Geosci., 101, 515-546, doi:10.1007/s00015-008-1283-z.

Steinmann, M. C. (1994), Die nordpenninischen Bündnerschiefer der Zentralalpen Graubündens: Tektonik, Stratigraphie und Beckenentwicklung, Ph.D. thesis, 220 pp., ETH Zurich, Zurich, Switzerland.

Stipp, M., B. Fügenschuh, L. P. Gromet, H. Stünitz, and S. M. Schmid (2004), Contemporaneous plutonism and strike-slip faulting: A case study from the Tonale fault zone north of the Adamello pluton (Italian Alps), Tectonics, 23, TC3004, doi:10.1029/ 2003TC001515 
Stöckhert, B., and T. V. Gerya (2005), Pre-collisional high pressure metamorphism and nappe tectonics at active continental margins: A numerical simulation, Terra Nova, 17, 102-110, doi:10.1111/j.1365-3121. 2004.00589.x

Thompson, P. H. (1976), Isograd patterns and pressuretemperature distribution during regional metamorphism, Contrib. Mineral. Petrol., 57, 277-295.

Todd, C. S., and M. Engi (1997), Metamorphic field gradients in the Central Alps, J. Metamorph. Geol., 15 , 513-530, doi:10.1111/j.1525-1314.1997.00038.x

Trommsdorff, V. (1966), Progressive Metamorphose kieseliger Karbonatgesteine in den Zentralalpen zwischen Bernina und Simplon, Schweiz. Mineral. Petrogr. Mitt., 46, 431-460.

Trommsdorff, V. (1990), Metamorphism and tectonics in the Central Alps: The Alpine lithospheric melange of Cima Lunga and Adula, Mem. Soc. Geol. Ital., 45, 39-49.

Trommsdorff, V., and J. A. D. Connolly (1996), The ultramafic contact aureole about the Bregaglia (Bergell) tonalite: Isograds and a thermal model, Schweiz. Mineral. Petrogr. Mitt., 76, 537-547.

Trommsdorff, V., and B. W. Evans (1977), Antigorite ophicabonates: Contact metamorphism in Val Malenco, Contrib. Mineral. Petrol., 62, 301-312, doi:10.1007/BF00371017.
Turcotte, D. L., and G. Schubert (2002), Geodynamics, 2nd ed., 456 pp., Cambridge Univ. Press, Cambridge, U. K.

Vernon, A. J., P. A. van der Beek, H. D. Sinclair, and M. K. Rahn (2008), Increase in late Neogene denudation of the European Alps confirmed by analysis of a fission-track thermochronology database, Earth Planet. Sci. Lett., 270, 316-329, doi:10.1016/j. eps1.2008.03.053.

von Blanckenburg, F. (1992), Combined high-precision chronometry and geochemical tracing using accessory minerals: Applied to the central-Alpine Bergell intrusion (central Europe), Chem. Geol., 100, 19-40, doi:10.1016/0009-2541(92)90100-J.

Wagner, G. A., D. S. Miller, and E. Jäger (1979), Fission track ages on apatite of Bergell rocks from central Alps and Bergell boulders in Oligocene sediments, Earth Planet. Sci. Lett., 45, 355-360, doi:10.1016/ 0012-821X(79)90136-5.

Wiederkehr, M., R. Bousquet, S. M. Schmid, and A. Berger (2008), From subduction to collision: Thermal overprint of HP/LT meta-sediments in the north-eastern Lepontine Dome (Swiss Alps) and consequences regarding the tectono-metamorphic evolution of the Alpine orogenic wedge, Swiss J. Geosci., 101, 127-155, doi:10.1007/s00015-0081289-6.

Wiederkehr, M., M. Sudo, R. Bousquet, A. Berger, and S. M. Schmid (2009), Alpine orogenic evolution from subduction to collisional thermal overprint: The ${ }^{40} \mathrm{Ar} /{ }^{39} \mathrm{Ar}$ age constraints from the Valaisan Ocean, Central Alps, Tectonics, 28, TC6009, doi:10.1029/2009TC002496.

Winter, J. D. (2001), An Introduction to Igneous and Metamorphic Petrology, 697 pp., Prentice Hall, Upper Saddle River, N. J.

Wittmann, H., F. von Blanckenburg, T. Kruesmann, K. P. Norton, and P. W. Kubik (2007), Relation between rock uplift and denudation from cosmogenic nuclides in river sediment in the Central Alps of Switzerland, J. Geophys. Res., 112, F04010, doi:10.1029/2006JF000729.

A. Berger, Institute for Geography and Geology, Copenhagen University, Øster Voldgade 10, DK-1350 København, Denmark. (ab@geo.ku.dk)

R. Bousquet, Institut für Geowissenschaften, Universität Potsdam, Karl-Liebknecht-Str. 24/25, D-14476 Golm, Potsdam, Germany.

M. Engi, Institute of Geological Sciences, University of Bern, Baltzerstr. 1-3, CH-3012 Bern, Switzerland.

S. M. Schmid, Institut für Geologisch Wissenschaften, Freie Universität Berlin, Malteserstr. 74-100, D-12249 Berlin, Germany.

M. Wiederkehr, Bundesamt für Landestopografie Swisstopo, Landesgeologie, Seftigenstr. 264, CH-3084 Wabern, Switzerland. 